Article

\title{
The Recent Change in the Italian Policies for Photovoltaics: Effects on the Energy Demand Coverage of Grid-Connected PV Systems Installed in Urban Contexts
}

\author{
Aldo Orioli *, Vincenzo Franzitta, Alessandra Di Gangi and Ferdinando Foresta \\ Dipartimento di Energia, Ingegneria dell'Informazione e Modelli Matematici (D.E.I.M.), \\ Università degli Studi di Palermo, Viale delle Scienze Edificio 9, 90128 Palermo, Italy; \\ vincenzo.franzitta@unipa.it (V.F.); alessandradigangi@dream.unipa.it (A.D.G.); nandoforesta@virgilio.it (F.F.) \\ * Correspondence: orioli@dream.unipa.it; Tel.: +39-091-2386-1914; Fax: +39-091-484-425
}

Academic Editor: Jayanta Deb Mondol

Received: 28 September 2016; Accepted: 8 November 2016; Published: 12 November 2016

\begin{abstract}
In July 2013, the Italian photovoltaic (PV) support policies changed the feed-in tariff (FIT) mechanism and turned to a tax credits program, which is currently in force. The aim of this paper is to investigate how such a radical change has influenced the electricity demand coverage of the PV systems installed in urban contexts. A methodology, which connects the economic assessment to a detailed architectural and energy suitability analysis, was applied to some case studies to analyse the relationships between the physical parameters related to multi-storey buildings (roof shapes, number of floors and area of flats) and the most relevant economic and financial features affecting the viability of rooftop PV systems. The study, which considers only the electricity produced by the PV systems that are economically profitable, highlighted that the tax credits scheme is even more effective in covering the electrical consumption of densely urbanised Italian city districts. The results, which are significantly influenced by the latitude of the analysed districts, underline the opportunity for governments to adopt PV promoting policies that are more sensitive to the amount of solar energy available in the different regions of their national territory.
\end{abstract}

Keywords: photovoltaic; feed-in tariff; tax credit

\section{Introduction}

The actual energy coverage of the grid-connected photovoltaic (PV) systems installed in urban contexts largely depends on the impact of the cost-benefit analysis. The economic evaluation plays a key role in the investment decision of householders, which has to be very accurate not only because the savings on the electricity bills due to the PV generation offset the costs related to the installation of PV systems. The economic outcome related to PV systems placed on multi-storeys buildings roofs implies the painstaking study of the interaction between the miscellaneous parameters closely linked to the morphological configurations of urban areas (building roof shape, number of floors and overshadowing effects of the surrounding buildings) and financial, economic and running factors (discount rate, inflation rate, price of the purchased electricity, price of the sold electricity, devices replacement and maintenance, insurance costs). Obviously, also the support mechanisms Feed-in tariff (FIT, net metering, tax credits, cash rebates, capital subsidies and renewable portfolio standards), which governments have enacted to promote PV dissemination and enforce the reduction of $\mathrm{CO}_{2}$ emission due to the use of fossil fuels, can significantly impact on the expected return on the investment and determine the PV technology success. The effectiveness of the promoting policies implemented by numerous countries has been widely analysed in literature. 
Net metering, which is the simplest incentive for renewables, allows residential and commercial electric customers to feed generated PV electricity that they not use back into the grid [1-7]. This allows customers to offset their electric consumption by the amount of energy that their PV systems generate. Using a specified meter that records the flow of electricity in both directions, consumers can benefit from the total amount of energy they produce, not just the electricity they consume locally. Unfortunately, due to the high costs of the PV electricity, net metering alone may be insufficient to put PV systems in competition with the other traditional energy production technologies [8].

By means of renewable portfolio standards a government places an obligation on electricity supply companies to produce a specified fraction of their electricity from renewable energy sources [3-6,9-12]. The companies are required to acquire renewable energy certificates, also known as tradable green certificates, which are typically equivalent to $1 \mathrm{MWh}$ of electricity created by a renewable resource. To better stimulate the PV development, countries have established targets, known as set-asides or carve-outs, which are provisions that require utilities companies to use a specific renewable source to account for a certain amount of generating capacity or a percentage of their retail electricity sales.

Tax credits are financial incentives based on a non-refundable personal income tax credit, which generally applies only to residential renewable energy systems [1,3-6,13]. Governments allow PV systems a credit equivalent to a fixed percentage of the installation price, which usually includes on-site preparation, equipment, labour cost, wiring and piping for connection to the grid. Some countries also adopted financial incentives in the form of cash rebates and capital subsidies, which are amounts of money paid to the PV system owners per watt-capacity of the installed PV field or to compensate a fixed percentage of the investment costs.

The FIT scheme provides a constant tariff guaranteed for electricity generated from PV and fed into the grid over a given period of time $[1-5,7,9-12,14-23]$. FIT payments may depend on the market price of electricity or not. In a fixed-price FIT, the total per-kWh payment is independent from the market price; in a premium-price FIT payment, the total payment is determined by adding a premium tariff, which can be constant or sliding, to the spot market electricity price. Despite FITs seem to be an effective incentive to boost PV technology growth, an optimal FIT must cover the PV project costs, plus an estimated profit, to reduce the investment risk and ensure a return to investors. The implementation of severe FIT de-escalation rates, justified by the PV device prices decrement observed over the last years, or even a PV support policy moratorium, may not guarantee a reliable economic return over the time and compromise the fulfilment of the electricity demand coverage that may be realistically obtained from renewable energy sources.

The FIT support, which was promoted in Italy since 2005 by means of some consecutive decrees named "Conto Energia", was discontinued in July 2013. At present, PV systems are incentivised by tax credits that are granted for ten years. Such a new promotion policy has significantly modified the economic convenience of PV systems in Italy. Despite many pessimistic predictions, it seems that the new approach may yield greater advantages for domestic investors and, in turn, increase the amount of electrical consumption covered by the electricity generated by the PV systems installed in densely urbanised areas. With the aim of quantifying the energy effects of the change in the Italian PV support policy, the FIT and current tax credits schemes have been compared for the districts of three densely urbanised Italian cities that are fair representative of the Italian latitudes. The paper is organised as follows: the Italian FIT and tax credits schemes are discussed in Section 2. In Section 3, the methodology used for evaluating the viability of the investment is outlined and the case studies are described. The last sections show the results concerning the effectiveness of both the analysed PV policy schemes on the electricity coverage, also considering the effects of the solar energy shading and mismatch between electricity generation and consumption.

\section{The Italian Support Policies for Photovoltaics}

Over the last years the electricity produced by the clean sources of renewable energies has significantly risen in Italy. The power generated by PV systems, which was only 39 GWh in 2007, 
reached 23,299 GWh at the end of 2014 [24,25]. An increase was observed for hydropower and wind power that were 32,815 GWh and 4030 GWh in 2007, respectively, and became 58,067 GWh and 14,966 GWh in 2014. The generation of geothermal electricity, which has varied from 5569 to $5541 \mathrm{GWh}$ during the same period of time, was almost constant. Figure 1 depicts the variation of the electricity generated by clean renewable sources since 2007 .

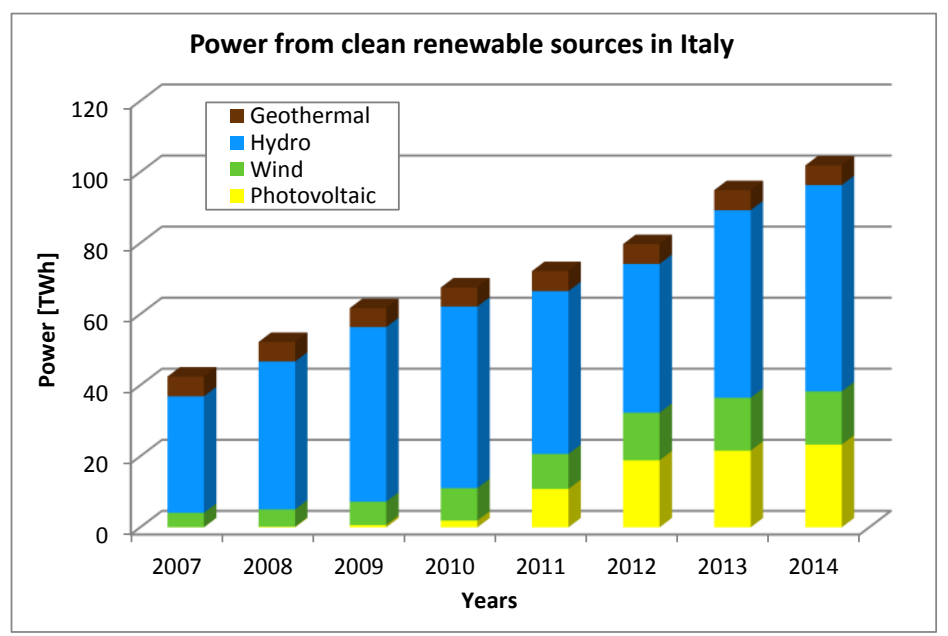

Figure 1. Power generation from clean sources of renewable energy in Italy.

At the end of 2014 the clean renewable electricity, which has reached $38.08 \%$ of the power produced in Italy, was 2.40 times the value measured in 2007. It is easy to observe that PV systems have played a dominant role in increasing the clean renewable electricity generation. Such a result is the long-term effect of the effective promoting policies implemented some years ago, which enhanced the diffusion of PV systems in Italy.

The first PV promoting initiative dates back to 2000 when the Italian government issued the "Photovoltaic roofs" program [26] that provided consistent financial supports-up to 75\% of the investment costs-to install PV systems with a peak power in the range 1 to $20 \mathrm{~kW}$. A maximum investment cost of $8005.08 € / \mathrm{kW}$ was fixed for the PV systems with a nominal power up to $5 \mathrm{~kW}$, whereas such a value was linearly decreased to $7230.40 € / \mathrm{kW}$ for an installed power of $20 \mathrm{~kW}$. The promoting initiative yielded the installation of PV systems for a global power of 27 MW in 2003. Unfortunately, the program had an important drawback as it did not reward the PV system energy efficiency and electricity production. Accordingly, many installed PV systems were out of order after few years because the producers thought it was not worth spending money to replace the damaged PV modules and inverters, whose cost was very high at that time.

In 2005, to put the European Union 2001/77/EC Directive [27] into effect, the Italian government issued a decree, named 1st "Conto Energia" [28,29], that adopted a FIT scheme to incentivise the PV systems diffusion. A premium of $0.445 € / \mathrm{kWh}$ was paid for the electricity generated by the PV systems with a peak power up to $20 \mathrm{~kW}$ and self-consumed by the producers; for the energy injected into the grid by the PV systems with a nominal power in the range 20 to $1000 \mathrm{~kW}$ a premium, varying from 0.460 to $0.490 € / \mathrm{kWh}$, was paid. In addition to the previous premiums, which had a duration of 20 years, a simplified purchase and resale arrangement was offered by the "Gestore Servizi Energetici" (GSE), which is the state-owned company that promotes and supports renewable energy sources in Italy, to pay the electricity fed into the grid. The electricity exported to the grid was paid at a guaranteed minimum price, which is updated annually by the Autorità per l'Energia Elettrica, il Gas e il Sistema Idrico (AEEG), Italian Regulatory Authority for electricity and gas, or at an average monthly price per hourly band, which is set on the Italian Power Exchange for the market area to which the PV system is connected. Such a purchase and resale arrangement is currently used. The net metering 
service, with a balancing period of 3 years, was alternatively proposed for the energy injected into the grid by the only PV systems with a peak power up to $20 \mathrm{~kW}$. The 1st "Conto Energia" expired in March 2006 when the 500 MW target of PV installed power was reached.

In 2007 the 2nd "Conto Energia" [30], which set a 1200 MW target of PV capacity to be installed at national level, was implemented. Besides simplified purchase and resale arrangements, the net metering service was alternatively proposed for the energy fed into the grid by the PV systems with a peak power up to $20 \mathrm{~kW}$. Different premiums varying from 0.360 to $0.490 € / \mathrm{kWh}$, depending on the PV system peak power and the used installation typology, were additionally paid for the electricity generated in the next 20 years. The greatest premiums were paid for the PV systems that used building integrated photovoltaic (BIPV) devices to replace architectural elements such as roofs, facades, balustrades, bus shelters, acoustic barriers, windows and sun blind shutters. A premium de-escalation rate of 2\%/year was fixed for the PV systems installed after 2008.

In 2009 the AEEG adopted a modified net metering service under which, besides the possibility of using the electricity injected into the grid to offset the electricity withdrawn from the grid for a period of 3 years, a compensatory contribution is paid to PV producers [31]. The contribution, which also covers part of the charges incurred by the customer for withdrawing electricity from the grid, is calculated considering the amount of electricity exported or imported by the PV system at the various different hours of each day in a given calendar year and the corresponding hourly market price of the electricity.

In 2010 the Italian government implemented the 3rd "Conto Energia" [32] that planned the installation of a number of regular PV systems (i.e., using a PV field made by joining commercial PV modules), innovative BIPV systems and concentrating PV (CPV) systems sufficient to reach a capacity of $3500 \mathrm{MW}$. Besides simplified purchase and resale arrangements for the energy injected into the grid by all kind of PV systems, the possibility of using the modified net metering service was optionally offered for the PV systems with a peak power up to $200 \mathrm{~kW}$. For each PV system typology different premiums, varying with the peak power of the installed PV field, were additionally paid settled for the electricity produced in the next 20 years. The premiums ranged from 0.251 to $0.402 € / \mathrm{kWh}$ for regular PV systems, from 0.370 to $0.440 € / \mathrm{kWh}$ for BIPV systems and from 0.280 to $0.370 € / \mathrm{kWh}$ for CPV systems.

At the beginning of the second semester 2011 the 4th "Conto Energia" [33] was implemented. Both the modified net metering service and simplified purchase and resale arrangements were alternatively offered for the energy injected into the grid by all types of PV systems. The additional premiums settled for the electricity generated by regular PV systems varied from 0.133 to $0.387 € / \mathrm{kWh}$, depending on the installed peak power and the month of the year. The premiums paid for the electricity generated ranged from 0.345 to $0.427 € / \mathrm{kWh}$ for BIPV systems and from 0.261 and $0.359 € / \mathrm{kWh}$ for CPV systems, depending on the installed peak power and the current semester of the year. The premiums had twenty years duration. The 4th "Conto Energia" expired at the end of August 2012 when the global amount of incentives paid by the Italian government reached the fixed target value of $6 \mathrm{M} € /$ year.

For the 5th "Conto Energia" [34], which started as soon as the previous "Conto Energia" ceased, the target value of $6.7 \mathrm{M} €$ /year for the global amount of the paid incentives was fixed. For each type of PV systems a different FIT was fixed for the electricity injected into the grid, depending on the peak power of the photovoltaic arrays and the current month. In addition, for the PV electricity self-consumed by producers in the next 20 years a premium was paid by the GSE. Table 1 lists the values of the FIT and premiums for the regular PV systems installed on buildings, which had to be provided with the energy performance certification. 
Table 1. FITs and premiums for PV systems installed on buildings.

\begin{tabular}{ccccc}
\hline $\begin{array}{c}\text { PV System Rated } \\
\text { Power }(\mathbf{k W})\end{array}$ & $\begin{array}{c}\text { September 2012-February 2013 } \\
\text { Feed-in Tariff } \\
(\boldsymbol{\epsilon} / \mathbf{k W h})\end{array}$ & $\begin{array}{c}\text { March 2013-August 2013 } \\
\text { Premium } \\
(\boldsymbol{€} / \mathbf{k W h})\end{array}$ & $\begin{array}{c}\text { Feed-in Tariff } \\
(\boldsymbol{\epsilon} / \mathbf{k W h})\end{array}$ & $\begin{array}{c}\text { Premium } \\
\mathbf{(} / \mathbf{k W h})\end{array}$ \\
\hline $1-3$ & 0.208 & 0.126 & 0.182 & 0.100 \\
$3-20$ & 0.196 & 0.114 & 0.171 & 0.089 \\
$20-200$ & 0.175 & 0.093 & 0.157 & 0.075 \\
$200-1000$ & 0.142 & 0.060 & 0.130 & 0.048 \\
$1000-5000$ & 0.126 & 0.044 & 0.118 & 0.036 \\
$>5000$ & 0.119 & 0.037 & 0.112 & 0.030 \\
\hline
\end{tabular}

The values of the FITs ranged from 0.217 to $0.288 € / \mathrm{kWh}$ for the BIPV systems and from 0.174 to $0.259 € / \mathrm{kWh}$ for the CPV systems. The premiums varied from 0.135 to $0.186 € / \mathrm{kWh}$ and from 0.092 to $0.157 € / \mathrm{kWh}$ for the BIPV and CPV systems, respectively. In addition to the previous premiums, for the energy injected into the grid by all types of PV systems the simplified purchase and resale arrangements and modified net metering service were also offered as possible alternatives to the current FIT. The 5th "Conto Energia" had a short life, as it ceased on the first days of July 2013.

To support the future installation of PV systems the Italian government opportunely implemented a tax credit program [35-37] that allows the owners or tenants of the building, on which the PV system is installed, to have ten annual tax refunds corresponding to a global benefit on the PV system costs equal to:

- $50 \%$ of the expenses incurred before the end of 2014;

- $40 \%$ of the expenses incurred during 2015;

- $36 \%$ of the expenses incurred after 2015.

The electricity injected into the grid is counted by the GSE considering the terms of the covenant with the PV producer, who can choose a simplified purchase and resale arrangement or the modified net metering service. Since the end of the 5th "Conto Energia", the lack of PV incentives has diffused the idea that it was not worth installing new PV systems, because no money was paid by the government to the investors. Such an idea, which is shared by many PV investors who used to get the money regularly paid by the government, is clearly disproved by the results presented in this paper.

\section{Methodology}

The assessment of the PV electricity potential at urban scale has been investigated by many authors. Some Israeli (Jerusalem, Tel Aviv, Haifa, Beersheba, Eilat) and Slovakian (Bardejov) cities were analysed by Hofierca et al. [38] and Vardimon [39] respectively. Bergamasco et al. [40] evaluated the PV energy collected by the available roof surface area in Turin (Italy). The Portuguese cities of Lisbon, Alcabideche and Oeiras were studied by Brito et al. [41], Redweik et al. [42], Santos et al. [43] and Amado et al. [44,45]. Kodysh et al. [46] presented a methodology for estimating solar potential on multiple building rooftops in Knoxville (TN, USA). A method to evaluate the adaptability of PV energy on urban façades was proposed and used by Esclapés et al. [47] for a representative area of Madrid (Spain).

Klironomos et al. [48] and Portolan dos Santos et al. [49] evaluated the potential of building integrated photovoltaic (BIPV) systems in Oinofyta (Greece) and Florianopolis (Brazil) respectively. Some districts of State College (PA, USA) and Bombay (India) were analysed by Choi et al. [50] and Singh et al [51] respectively. The urban PV potential of Cottbus (Germany), Georgetown (Malaysia) and Tokyo (Japan) was assessed by Schwarz et al. [52], Latif et al. [53] and Stoll et al. [54] respectively. Strzalka et al. [55] used a modern district near Stuttgart (Germany) to evaluate the potential of PV energy and the local own consumption of electricity produced. An urban area of Valparaiso (Chile) 
constituting 366 houses was studied by Araya-Muñoz [56]. Talavera et al. [57] analysed the University of Jaén Campus (Spain).

In order to evaluate the effects of the two different support schemes on the level of coverage of the electricity consumption of rooftop PV systems, three case studies regarding the districts of cities representative of the urban morphologies and latitudes of southern, central and northern Italy, were investigated. A specific methodology [58], which combines the analysis of the economic convenience of PV systems to a detailed rooftop architectural and energy suitability analysis, was adopted. Accordingly, the interaction between the number of floors and the roof shapes of the buildings was considered with the aim of inferring the specific sizes of the PV systems that can be installed by each building co-owner, the associated electricity generation and, in turn, the coverage of the electricity demand in the districts. Then, the economic analysis of the PV systems was performed by means of the net present value (NPV) assuming both the FITs and tax credits schemes and considering all costs (PV and electrical devices, maintenance and management, insurance, replacement of PV panels and inverters), all benefits (reduced electricity bills, sold PV electricity, FITs, premiums and tax credits) the decrease in the PV panel efficiency and the variation of the electricity price and inflation rate. Only the electricity produced by the economically advantageous PV systems was used to assess the coverage of the electricity consumption in the districts. Three different temporal scenarios were assumed:

1. At the end of the FIT scheme (June 2013);

2. At the beginning of the tax credits scheme (July 2013);

3. 18 months after the beginning of the tax credits scheme (December 2014).

A sensitivity analysis was also carried out considering different levels of load mismatch and solar energy shading.

\subsection{Case Studies}

Three districts located in the Italian cities of Palermo (Latitude $38.0^{\circ} \mathrm{N}$, Longitude $13.4^{\circ} \mathrm{E}$ ), Rome (Latitude $41.0^{\circ} \mathrm{N}$, Longitude $12.0^{\circ} \mathrm{E}$ ) and Milan (Latitude $45.0^{\circ} \mathrm{N}$, Longitude $9.0^{\circ} \mathrm{E}$ ) were selected as case studies to assess the effects of the integration of PV systems in urban contexts; as it is shown in Figure 2, the cities are fair representative of the Italian latitudes.

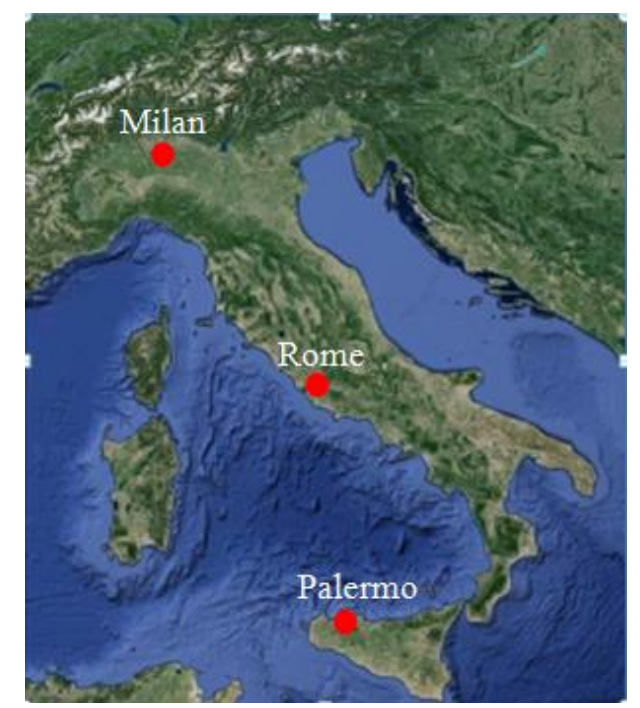

Figure 2. The analysed cities (provided by Google Maps).

The analysed districts are shown in Figures 3-5. Each district, which was surveyed by means of Google Earth ${ }^{\mathrm{TM}}$ program is characterised by specific road alignments and orientations 
(Palermo: $117^{\circ}$ East of South and $153^{\circ}$ West of South; Rome: $107^{\circ}$ East of South and $253^{\circ}$ West of South; Milan: $147^{\circ}$ East of South and $213^{\circ}$ West of South).

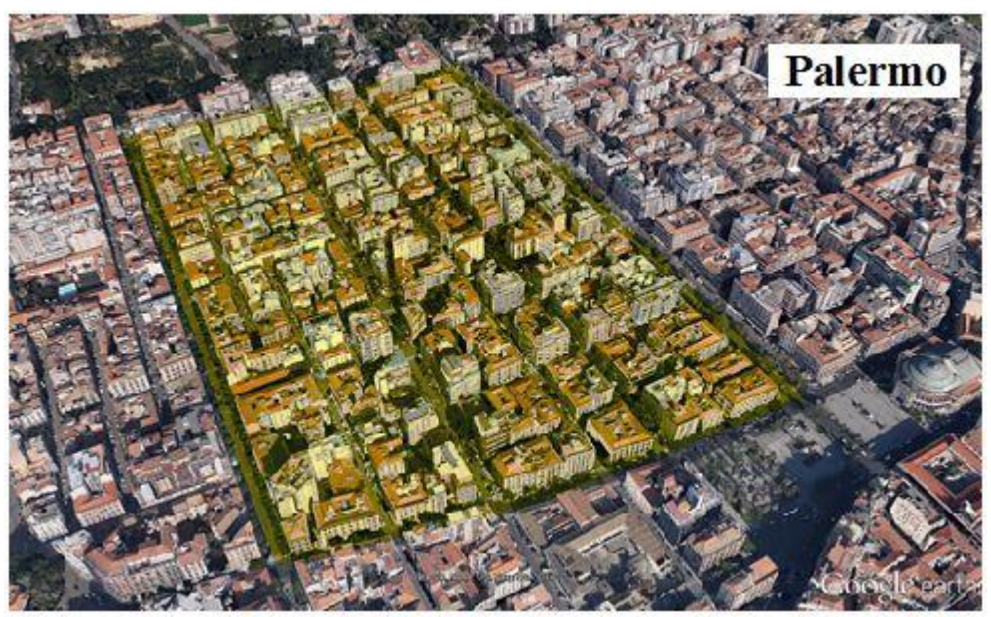

Figure 3. The study area of Palermo (provided by Google Earth ${ }^{\mathrm{TM}}$ ).

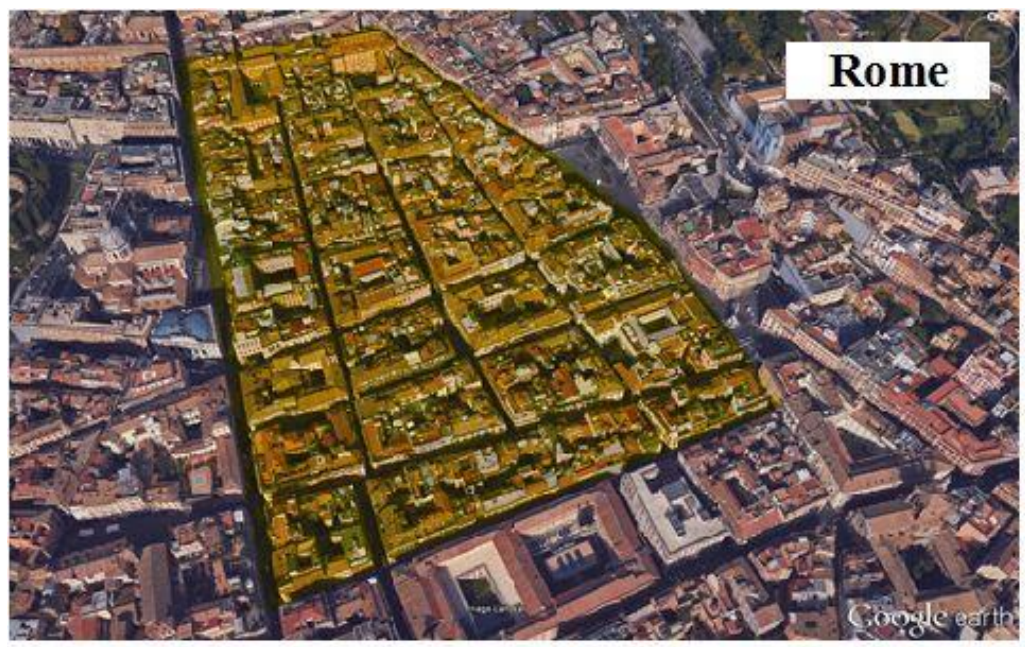

Figure 4. The study area of Rome (provided by Google Earth ${ }^{\mathrm{TM}}$ ).

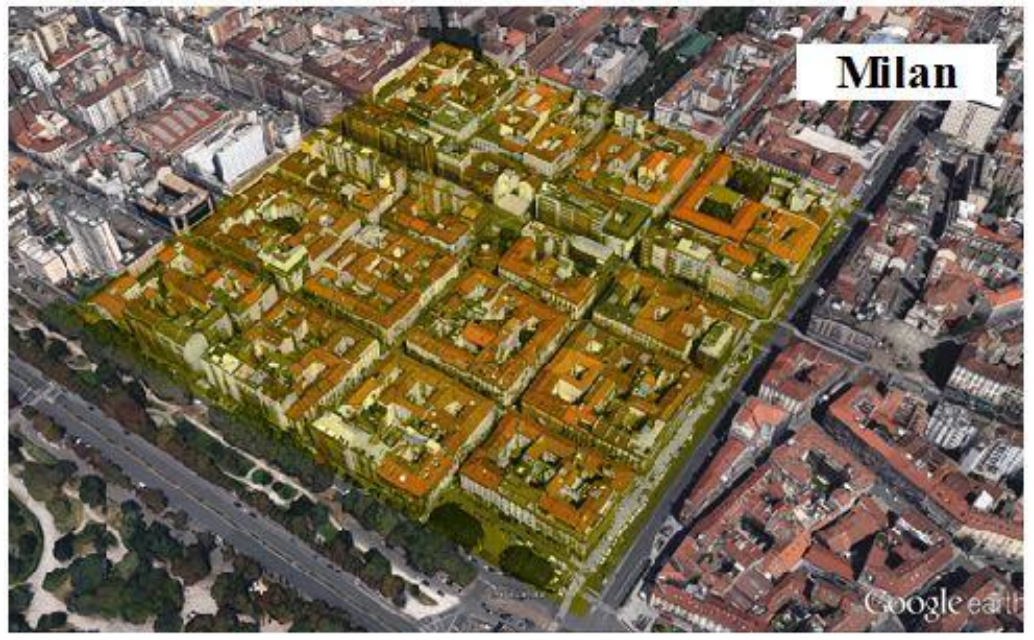

Figure 5. The study area of Milan (provided by Google Earth ${ }^{\mathrm{TM}}$ ). 
The districts, which were measured using the images provided by Google Earth ${ }^{\mathrm{TM}}$, cover an area of 269,000 $\mathrm{m}^{2}, 126,000 \mathrm{~m}^{2}$ and 154,000 $\mathrm{m}^{2}$ for Palermo, Rome and Milan, respectively; the corresponding surfaces occupied by the buildings measure $109,207 \mathrm{~m}^{2}, 78,826 \mathrm{~m}^{2}$ and $99,817 \mathrm{~m}^{2}$.

\subsection{Architectural Analysis}

The size of the PV fields that can be installed on the rooftop of a building is affected by the surface available for each flat-owner. Accordingly, a reliable assessment of the PV systems that can be realistically installed involves the study of the relationships between the roof shapes the number of floors and the surface of the flats in the buildings. For this purpose, the slanted roofs were classified depending on their configuration (gable, hip and skillion) and the main orientations of the buildings in each district. Table 2 shows the selected roof shapes, direction of slope and the areas of the classified roofs.

Table 2. Classified areas of the slanted roofs.

\begin{tabular}{|c|c|c|c|c|c|c|c|c|}
\hline Roof Type & T1 & T2 & T3 & $\mathrm{T} 4$ & T5 & T6 & T7 & T8 \\
\hline \multicolumn{9}{|l|}{ City } \\
\hline Palermo $\left(\mathrm{m}^{2}\right)$ & 8162 & 12901 & 2690 & 2031 & 2144 & 2219 & 1582 & 2880 \\
\hline Rome $\left(\mathrm{m}^{2}\right)$ & 7495 & 5253 & 299 & 1032 & 536 & 628 & 1506 & 1134 \\
\hline Milan $\left(\mathrm{m}^{2}\right)$ & 16,194 & 31,850 & 4954 & 3910 & 4325 & 4150 & 1695 & 1256 \\
\hline Roof Type & T9 & T10 & T11 & T12 & T13 & T14 & T15 & T16 \\
\hline \multicolumn{9}{|l|}{ City } \\
\hline Palermo $\left(\mathrm{m}^{2}\right)$ & 2296 & 1683 & 3298 & 2906 & 3787 & 3765 & 3618 & 4183 \\
\hline Rome $\left(\mathrm{m}^{2}\right)$ & 5530 & 4794 & 3997 & 3822 & 2385 & 606 & 779 & 882 \\
\hline Milan $\left(\mathrm{m}^{2}\right)$ & 1803 & 1605 & 3278 & 2710 & 493 & 966 & 571 & 887 \\
\hline
\end{tabular}

A different criterion of classification was used for flat roofs. Flat roofs were subdivided into five groups according to their surface and a building, whose roof area was very close to the average value of the group surfaces, was selected as representative of each group. Table 3 lists the surface and the shape of the selected representative buildings along with the areas of the classified flat roofs.

Table 3. Representative flat roofs (FRs).

\begin{tabular}{|c|c|c|c|c|c|c|}
\hline City & Item & FR1 & FR2 & FR3 & FR4 & FR5 \\
\hline \multirow{3}{*}{ Palermo } & & $265 \mathrm{~m}^{2}$ & $387 \mathrm{~m}^{2}$ & $482 \mathrm{~m}^{2}$ & $717 \mathrm{~m}^{2}$ & $1394 \mathrm{~m}^{2}$ \\
\hline & $\begin{array}{l}\text { Representative } \\
\text { building }\end{array}$ & & & & & \\
\hline & Flat roofs area & $3065 \mathrm{~m}^{2}$ & $4267 \mathrm{~m}^{2}$ & $5501 \mathrm{~m}^{2}$ & $9235 \mathrm{~m}^{2}$ & $15,834 \mathrm{~m}^{2}$ \\
\hline \multirow{3}{*}{ Rome } & & $104 \mathrm{~m}^{2}$ & $122 \mathrm{~m}^{2}$ & $136 \mathrm{~m}^{2}$ & $179 \mathrm{~m}^{2}$ & $296 \mathrm{~m}^{2}$ \\
\hline & $\begin{array}{l}\text { Representative } \\
\text { building }\end{array}$ & & & & & \\
\hline & Flat roofs area & $2321 \mathrm{~m}^{2}$ & $2660 \mathrm{~m}^{2}$ & $2924 \mathrm{~m}^{2}$ & $3942 \mathrm{~m}^{2}$ & $6360 \mathrm{~m}^{2}$ \\
\hline \multirow{3}{*}{ Milan } & & $113 \mathrm{~m}^{2}$ & $138 \mathrm{~m}^{2}$ & $178 \mathrm{~m}^{2}$ & $257 \mathrm{~m}^{2}$ & $424 \mathrm{~m}^{2}$ \\
\hline & $\begin{array}{l}\text { Representative } \\
\text { building }\end{array}$ & & & & & \\
\hline & Flat roofs area & $1228 \mathrm{~m}^{2}$ & $1632 \mathrm{~m}^{2}$ & $2155 \mathrm{~m}^{2}$ & $2604 \mathrm{~m}^{2}$ & $4478 \mathrm{~m}^{2}$ \\
\hline
\end{tabular}


Table 4 lists the roof areas of the districts and the other surfaces, such as terraces or balconies, which are too small for the PV array installation.

Table 4. Distribution of the roof surfaces of the districts.

\begin{tabular}{cccc}
\hline City & Slanted Roofs & Flat Roofs & Other Surfaces \\
\hline \multirow{2}{*}{ Palermo } & $60,145 \mathrm{~m}^{2}$ & $37,902 \mathrm{~m}^{2}$ & $11,160 \mathrm{~m}^{2}$ \\
& $(55.07 \%)$ & $(34.71 \%)$ & $(10.22 \%)$ \\
\hline \multirow{2}{*}{ Roma } & $40,677 \mathrm{~m}^{2}$ & $18,206 \mathrm{~m}^{2}$ & $19,943 \mathrm{~m}^{2}$ \\
& $(51.60 \%)$ & $(23.10 \%)$ & $(25.30 \%)$ \\
\hline \multirow{2}{*}{ Milano } & $80,647 \mathrm{~m}^{2}$ & $12,097 \mathrm{~m}^{2}$ & $7073 \mathrm{~m}^{2}$ \\
& $(80.79 \%)$ & $(12.12 \%)$ & $(7.09 \%)$ \\
\hline
\end{tabular}

Each representative slanted and flat roof was connected to the respective number of building storeys. The percentage distributions of slanted and flat roofs, versus the number of floors, are shown in Figures 6 and 7.

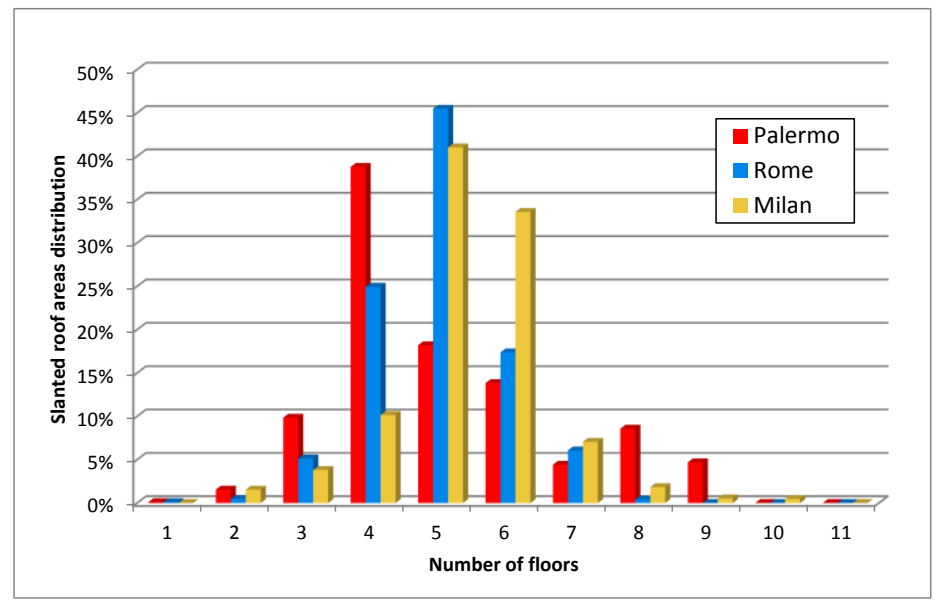

Figure 6. Distribution of the slanted roofs areas versus the number of floors.

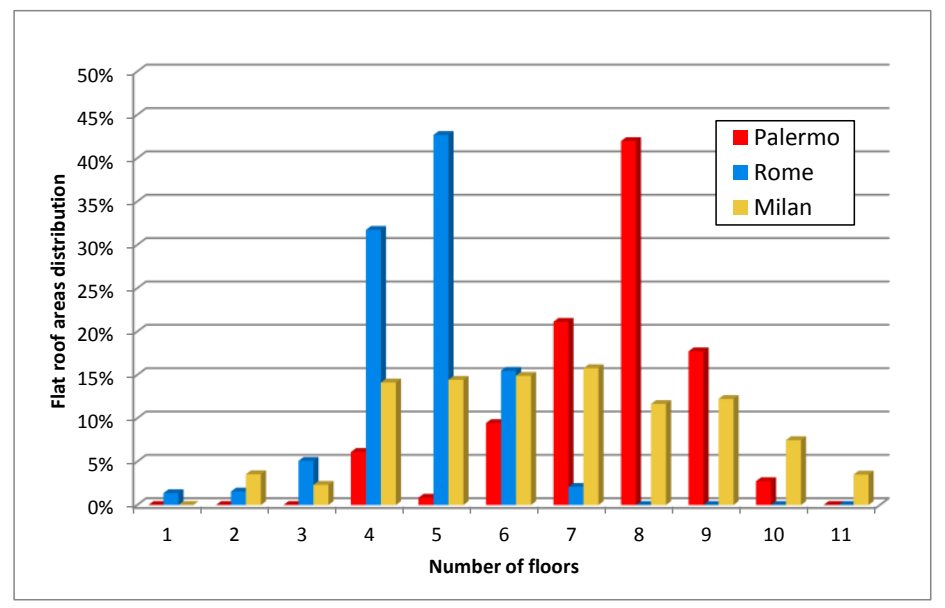

Figure 7. Distribution of the flat roofs areas versus the number of floors.

In the city of Palermo the majority of slanted roofs belong to four-storey buildings, whereas most of the flat roof surfaces cover eight-storey buildings. Most of the slanted and flat roofs in Rome belong to five-storey buildings. A regular distribution of flat roofs, with a maximum in correspondence 
of seven-storey buildings, is observed for Milan, whereas the majority of the slanted roofs cover five-storey buildings.

\subsection{Electricity Production}

The exact assessment of the PV electricity production of the districts is an arduous task. Actually, the electricity production is different for each building because the number and size of the PV arrays is affected by the shape of the building roof, whose area has to be parcelled out considering the number and surface of the flats in the building.

For calculations it was assumed that each flat had a standard surface of $162 \mathrm{~m}^{2}$ and a fixed dimension (width or length) of $9 \mathrm{~m}$. For each roof type, the roof surface was divided by the number of flats in order to establish the surface available for each co-owner and, in turn, the size of the PV array to be installed. Due to the presence of 21 roof-types and 11-storey buildings, 231 different types of PV systems had to be analysed. The PV fields were built with commercial PV panels Kyocera KD210GH-2PU that were located with the same pitch of the slanted roof surfaces (approximately $20^{\circ}$ above the horizontal for the district of Rome, and $25^{\circ}$ for Palermo and Milan) also considering a sufficient room for installation and maintenance. For the flat roofs it was assumed that the panels were oriented to the south with a pitch of $31^{\circ}$, which is the most efficient for the analysed cities. From calculations performed for the analysed districts, it was verified that, if the PV arrays were built selecting the two main building axes, a greater number of PV modules may be installed but a smaller amount of electricity would be produced. The distance between the rows of the PV array was set accordingly to the national electric standard [59], which requires that no part of the PV modules is shaded between 10:00 a.m. and 2:00 p.m. on the winter solstice. Moreover, in designing the shapes of the PV arrays, it was geometrically verified that the shadows thrown by balustrades, elevator housings and other obstructions never cover any part of each PV panel from 10:00 a.m. to 2:00 p.m. on the winter solstice.

The electricity calculations were carried out by means of PVsyst 5.06 [60] that determines the electricity produced by the PV systems considering the electrical characteristics of the PV panels and solar inverters issued by the manufacturers and using data of solar irradiance and air temperature that are specific to the given location and different for each day of the year. SMA Sunny Boy solar inverters [61,62] adequately sized for the number of panels of each PV array were used. Thee SMA Sunny Boy solar inverters use a maximum power point tracking method based on the Optitrac algorithm [63].

The energy generated by each type of PV system was divided by the corresponding roof-type surface in order to get the per square meter value of the PV generation that is sensitive to the number of the building storeys. Such value was multiplied by the respective global roof type surface of the district that cover the same number of storeys and, finally, the results were added to calculate the global PV production of the district. Table 5 lists the results of the PV electricity calculation.

With reference to the slanted and flat roof areas of the districts, the installed PV systems produce $91.03 \mathrm{kWh} / \mathrm{m}^{2}$ every year in Palermo, $81.89 \mathrm{kWh} / \mathrm{m}^{2}$ in Rome and $63.53 \mathrm{kWh} / \mathrm{m}^{2}$ in Milan. The differences in the values are obviously due to the different latitudes and urban morphologies of the analysed cities. Assuming a value of the yearly global horizontal solar irradiation of $1690 \mathrm{kWh} / \mathrm{m}^{2}$ for Palermo, $1549 \mathrm{kWh} / \mathrm{m}^{2}$ for Rome and $1255 \mathrm{kWh} / \mathrm{m}^{2}$ for Milan, the PV electricity is produced with values of the conversion efficiency varying from of $5.39 \%, 5.29 \%$ and $5.06 \%$ for the three cities, respectively. If the gross areas of the district are considered, the yearly PV production lowers to $33.18 \mathrm{kWh} / \mathrm{m}^{2}, 38.27 \mathrm{kWh} / \mathrm{m}^{2}$ and $38.26 \mathrm{kWh} / \mathrm{m}^{2}$ for Palermo, Rome and Milan, respectively. The corresponding conversion efficiencies are equal to $1.96 \%, 2.47 \%$ and $3.05 \%$ for Palermo, Rome and Milan, respectively. Such anomalous values, which apparently contrast with the yearly global horizontal solar irradiation of the cities, are mainly due to the different percentages of flat roofs in the analysed districts ( $34.71 \%$ for Palermo, $23.10 \%$ for Rome and $12.12 \%$ for Milan), which resulted to be less energy efficient than the slanted roofs. 
Table 5. PV electricity produced by slanted and flat roofs.

\begin{tabular}{|c|c|c|c|c|c|c|}
\hline \multirow{3}{*}{$\begin{array}{l}\text { Number of } \\
\text { Floors }\end{array}$} & \multicolumn{6}{|c|}{ PV Electricity Produced (kWh/Year) } \\
\hline & \multicolumn{2}{|c|}{ Palermo } & \multicolumn{2}{|c|}{ Rome } & \multicolumn{2}{|c|}{ Milan } \\
\hline & Slanted Roofs & Flat Roofs & Slanted Roofs & Flat Roofs & Slanted Roofs & Flat Roofs \\
\hline 1 & 6751.50 & 0.00 & 5364.58 & 9674.55 & 0.00 & 0.00 \\
\hline 2 & $107,472.26$ & 0.00 & $17,613.41$ & $10,976.14$ & $95,021.24$ & 8556.37 \\
\hline 3 & $579,218.44$ & 0.00 & $233,292.23$ & $29,500.64$ & $222,645.90$ & 4605.91 \\
\hline 4 & $2,540,303.18$ & $166,946.48$ & $1,070,826.52$ & $189,063.26$ & $606,795.84$ & $34,858.78$ \\
\hline 5 & $1,085,471.38$ & $14,596.56$ & $1,926,091.64$ & $250,710.37$ & $2,447,805.09$ & $39,258.28$ \\
\hline 6 & $749,020.15$ & $265,273.49$ & $738,447.06$ & $75,476.66$ & $1,720,776.51$ & $32,608.42$ \\
\hline 7 & $246,406.33$ & $610,023.03$ & $231,728.43$ & $12,851.51$ & $387,016.84$ & $35,804.41$ \\
\hline 8 & $475,982.47$ & $1,281,022.04$ & $20,516.25$ & 0.00 & $122,127.48$ & $27,064.24$ \\
\hline 9 & $242,950.62$ & $480,309.51$ & 0.00 & 0.00 & $24,828.47$ & $27,368.88$ \\
\hline 10 & 0.00 & $73,344.52$ & 0.00 & 0.00 & $28,602.08$ & $16,410.02$ \\
\hline 11 & 0.00 & 0.00 & 0.00 & 0.00 & 0.00 & $10,138.82$ \\
\hline Total & $6,033,576.32$ & $2,891,515.63$ & $4,243,880.13$ & $578,253.13$ & $5,655,619.45$ & $236,674.13$ \\
\hline
\end{tabular}

\subsection{Coverage of the Electricity Demand}

The level of integration of PV systems installed on buildings can be assessed by means of gross energy cover factor $C_{P V}[64,65]$, which compares the electricity produced to the energy demands of the analysed districts:

$$
C_{P V}=\frac{E_{P V}}{D_{\text {Total }}} \cdot 100
$$

in which $E_{P V}$ represents the electricity produced by the totality of the installed PV systems and $D_{\text {Total }}$ is the electrical energy demand of the district. $D_{\text {Total }}$ can be derived by the information issued for the districts by the major local electricity transmission grid operators. Table 6 lists the data officially issued by Terna [66], main Italian electricity transmission grid operator, and Istat, Italian National Institute of Statistics [67], which were used to calculate the yearly electricity consumption of a household living in a standard flat of $162 \mathrm{~m}^{2}$.

Table 6. Energy and statistic data of the analysed cities.

\begin{tabular}{cccc}
\hline Energy and Statistic Data & Palermo & Rome & Milan \\
\hline Domestic electricity consumption in the province $(\mathrm{GWh} /$ year $)$ & 1530.90 & 5703.80 & 4029.90 \\
\hline Area of inhabited flats in the city $\left(\mathrm{m}^{2}\right)$ & $24,920,851$ & $103,499,074$ & $50,824,652$ \\
Number of inhabitants in the province & $1,243,585$ & $3,997,465$ & $3,038,420$ \\
Number of inhabitants in the city & 657,561 & $2,617,175$ & $1,242,123$ \\
\hline Average number of inhabitants in the standard flat & 4.27 & 4.10 & 3.96 \\
\hline Electricity consumption in the standard flat $(\mathrm{kWh} /$ year) & 5262.1 & 5845.09 & 5251.12 \\
\hline
\end{tabular}

The results of the calculations of factor $C_{P V}$ are depicted in Figure 8.

The installed PV systems cover $42.8 \%, 39.5 \%$ and $34.4 \%$ of the domestic electrical consumptions of the analysed districts of Palermo, Rome and Milan, respectively. The energy production is mainly due to the roofs covering four-storey buildings in Palermo, and of five-storey buildings in Rome and Milan. Such figures represent the maximum values of the energy cover factor because the calculus of the PV electricity was performed without considering the lack of solar irradiance due to the shadowing of obstructions, which is quite likely in densely urbanised contexts. Moreover, a part of the PV generation may not be locally used and exported to the grid because it exceeds the electricity demand of the flat or because the instantaneous perfect correspondence between demand and generation is quite improbable. Obviously, the electricity consumed after sunset and before dawn will never be compensated by the energy produced by a PV system not equipped with batteries. To estimate 
night-time demands $D_{\text {night }}$ it was assumed that the following appliances were working in the standard flat from dusk to dawn [68-71]:

- Lamps: $85 \mathrm{~W}$ from $\mathrm{T}_{\mathrm{i}}$ to 23:00 and from 07.00 to $\mathrm{T}_{\mathrm{f}}$;

- Refrigerator: $90 \mathrm{~W}$ from $\mathrm{T}_{\mathrm{i}}$ to $24: 00$ and from 00.00 to $\mathrm{T}_{\mathrm{f}}$;

- Television + P.C.: $75 \mathrm{~W}$ from $\mathrm{T}_{\mathrm{i}}$ to $23: 00$ and from 07.00 to $\mathrm{T}_{\mathrm{f}}$;

in which $T_{i}$ was set one hour before sunset and $T_{f}$ one hour after dawn in order to consider that the electricity generated by the PV systems is quite small at the beginning and at the end of the day; sunset and dawn on 15th of each month were considered. In Table 7 the calculated values of day-time demand $D_{\text {day }}$ along with the values of $D_{\text {night }}$ are listed.

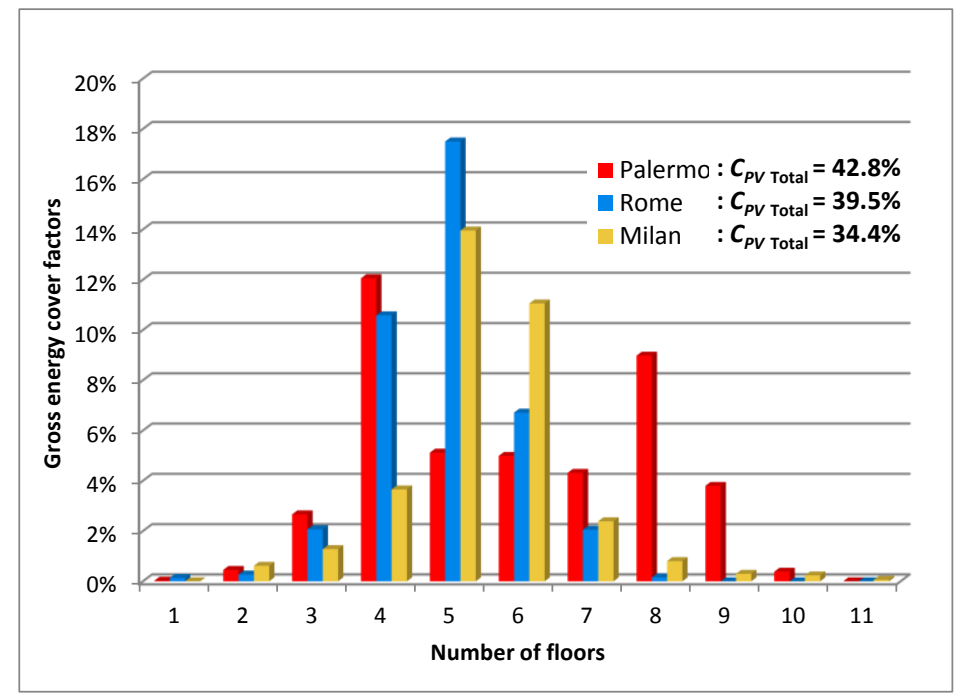

Figure 8. Yearly gross energy cover factors for the whole districts versus the number of floors.

Table 7. Electricity yearly consumption of the standard flat.

\begin{tabular}{cccc}
\hline \multirow{2}{*}{ City } & \multicolumn{3}{c}{ Consumption (kWh/Year) } \\
\cline { 2 - 4 } & Night-Time & Day-Time & Total \\
\hline Palermo & 609.6 & 4652.5 & 5262.1 \\
Rome & 648.1 & 5197.0 & 5845.1 \\
Milan & 624.8 & 4626.3 & 5251.1 \\
\hline
\end{tabular}

The load mismatch, caused by the lack of simultaneity between generation and consumption, and its impact on the operation of the grid is a relevant topic in the assessment of PV systems [72-86]. Due to the load mismatch, the grid managers are expected to provide the grid with a greater degree of flexibility and adopt smart energy management strategies. The presence of the load mismatch due to the incorrect habits in using the electrical appliances can cause the occurrence of disadvantageously purchasing electricity from the grid and/or wasting the unused PV energy. The effects of the load mismatch are even more evident if the time-of-using and real-time electricity pricing are considered $[87,88]$. Because the grid parity has not been completely reached in many countries, when almost all PV electricity is used by the PV system owner, the economic investment can be very convenient because the selling price is usually greater than the purchase price. Adversely, if only a very small part of the PV electricity is generated, and simultaneously used by the household appliances, the surplus would be sold off and it would be necessary to pay for some electricity imported from the grid later on. Moreover, because some duties must be also paid for both the purchased and sold electricity, the economic convenience may result very little. 
Among the indicators proposed by some authors to consider the effect of the mismatch between generated and consumed electricity [81,83-85], the load match index, which represents the percentage of the electrical demand that is covered by the generation of all $N_{P V}$ PV systems over the considered evaluation period $T$, is used in this paper. Load match index $\gamma_{D}$ can be calculated with the following equation:

$$
\gamma_{D}=\frac{\sum_{j}^{N_{P V}}\left(\sum_{i}^{i+N} \min \left[E_{P V, j}(i), D_{j}(i)\right]\right)}{\sum_{j}^{N_{P V}}\left(\sum_{i}^{i+N} D_{j}(i)\right)} \cdot 100
$$

in which $N$ is the number of samples in the considered evaluation period $T ; E_{P V, j}(i)$ and $D_{j}(i)$ are the PV generation and the demand of the $j$-th PV system during the generic $i$-th time interval, respectively. When only the yearly data of the energy are available, load match index $\gamma_{D}$ of the district may be approximated with the expression:

$$
\gamma_{D}=\frac{\sum_{j=1}^{N_{P V}} \min \left[E_{P V, j}^{*}, D_{j}^{*}\right]}{\sum_{j=1}^{N_{P V}} D_{j}^{*}} \cdot 100
$$

in which $E_{P V, j}^{*}$ is the PV generation of the $j$-th PV system and $D_{j}^{*}$ is the electrical demand of the flat powered by the $j$-th PV system, over the year. When the PV generation is sufficient, the day-time energy demand can be covered by the PV electricity only if there is a perfect simultaneity between PV generation and local consumption. Obviously, if no energy storage is installed, the electricity $D_{\text {Night }}$ consumed after sunset and before dawn can be compensated only by the grid. The portion of $D_{\text {Day }}$ that is covered by the PV electricity mainly depends on the habits of the households in using the electrical appliances. A household, which does not intend to waste the energy produced by its PV system, may only try to reschedule the use of the domestic appliances in order to increase the household consumption during the PV generation. Modern building automation may provide more efficient solutions to manage the appliances that have the highest consumption. Smart control systems, able to forecast the solar potential and the PV generation up to 2 days, with hourly resolution, have been recently presented [89].

It may be very difficult to settle realistic values of the energy demand that is satisfied by the electricity produced by each PV system of the district. This is the reason why, in this paper it was considered convenient to address the problem of the load mismatch by means of a sensitivity analysis based of the available yearly energy data. To reach that purpose it is useful to introduce the following utilization coefficient $c_{u}$ :

$$
c_{u}=\frac{D_{\text {Match }, j}}{D_{D a y, j}}
$$

where $D_{\text {Match }, j}$ and $D_{D a y, j}$ represent the amount of the matched yearly demand and the day-time yearly demand of the $j$-th PV system, respectively. The electricity demand of a PV system can be split as:

$$
D_{j}^{*}=D_{D a y, j}+D_{N i g h t, j}=D_{M a t c h, j}+D_{M i s m, j}
$$

where $D_{M i s m, j}$ and $D_{N i g h t, j}$ are the amount of mismatched yearly demand and the night-time yearly demand of the $j$-th PV system, respectively. Coefficient $c_{u}$ varies from 0 , when no PV electricity is used, to 1 , when all PV electricity covers the day-time consumptions. By means of the above equations the load match index of the district can be related to utilization coefficient $c_{u}$ : 


$$
\gamma_{D}\left(c_{u}\right)=\frac{\sum_{j}^{N_{P V}} \min \left[E_{P V, j^{\prime}}^{*}, c_{u} D_{\text {Day, }, j}\right]}{\sum_{j}^{N_{P V}} D_{j}^{*}} \cdot 100=\frac{\sum_{j}^{N_{P V}} E_{P V l o a d, j}^{*}\left(c_{u}\right)}{D_{\text {Total }}} \cdot 100
$$

Load match index $\gamma_{D}\left(c_{u}\right)$ is sensitive to the load mismatch and, if $c_{u}=0$, then $\gamma_{D}\left(c_{u}\right)=0$. The maximum value of the load match index can be less than $100 \%$ for two main reasons: (1) a PV system that has an undersized PV panel array will never cover the day-time electricity demand of the household; (2) even a PV system with an oversized PV panel array may not cover the household demand if some amount of the energy produced is not simultaneously consumed and no battery storage system is used.

\subsection{Economic Analysis}

Different measures of the economic value of an investment can be used depending on the peculiarities of the analysed problem [90]. In the present paper the NPV, which is typically used when only one set of investments can be selected, is considered. The NPV considers the full cost of possible alternatives, including direct costs such as capital costs, operations and maintenance costs (O\&M), as well as external costs, such as environmental costs. The NPV is calculated with the following formula:

$$
\mathrm{NPV}=\sum_{t=1}^{N_{t}} \frac{C F_{t}}{(1+k)^{t}}-C_{0}
$$

where $N_{t}$ is the lifetime of the investment, $C F_{t}$ is the cash flow related to the generic $t$-th year, $C_{0}$ is the initial investment cost and $k$ is the discount rate, which is the index that represents the average expected return on the investor's assets. The cash flow, which is defined as the movement of money into or out of a business, project or financial product, corresponds to the difference between all yearly disbursements (device replacements, operations, maintenance, servicing, insurance, finance costs, taxes, etc.) and benefits (revenues from the sold electricity, paid incentives, savings from the electricity bills, etc.).

The cash flows were calculated for 20 years, which is the duration for which FIT incentives provided in Italy. In Table 8 the costs of the PV components are listed; costs were assumed from the market prices of components, considering the cost for labour, fitter wages and value added tax (VAT).

Table 8. Costs of PV system components.

\begin{tabular}{cccc}
\hline Component & June 2013 (€) & July 2013 (€) & December 2014 (€) \\
\hline PV panel 210 Wp & 269.50 & 267.10 & 223.10 \\
Roof-top mounting system (1 PV panel) & 76.95 & 77.05 & 76.90 \\
On-roof mounting system (1 PV panel) & 48.90 & 49.00 & 48.90 \\
Connectors for PV panel & 10.50 & 10.50 & 10.50 \\
$4 \mathrm{~mm}^{2}$ DC cabling (1 metre) & 2.00 & 1.95 & 1.85 \\
6 mm AC cabling (1 metre) & 2.40 & 2.30 & 2.20 \\
Inverter Maximum Power Point Tracker (MPPT) 1.1 kW & 826.20 & 812.80 & 735.00 \\
Inverter MPPT 1.7 kW & 1099.40 & 1081.60 & 978.00 \\
Inverter MPPT 2.5 kW & 1442.90 & 1419.60 & 1283.70 \\
Inverter MPPT 3.0 kW & 1571.20 & 1545.70 & 1397.80 \\
Inverter MPPT 3.6 kW & 2046.00 & 2012.90 & 1820.20 \\
Inverter MPPT 5.0 kW & 2528.60 & 2487.60 & 2249.50 \\
Inverter MPPT 7.0 kW & 2687.80 & 2644.30 & 2391.20 \\
Inverter MPPT 8.0 kW & 2824.40 & 2778.70 & 2512.70 \\
Main switchboard & 649.70 & 650.5 & 649.20 \\
\hline
\end{tabular}

The profits are related to the gain for the avoided electricity bill cost, sold electricity and incentives. The electricity bills were calculated considering the difference between the bills corresponding to the electricity demand and those which are referred to the energy consumed while the PV systems are 
producing electricity. To calculate the bills, the electricity tariffs issued by the AEEG for domestic consumers with an electricity capacity of $3 \mathrm{~kW}$ were used [91]. Table 9 lists the data issued for the third trimester of 2013 and the fourth trimester of 2014.

Table 9. Electricity tariff in Italy.

\begin{tabular}{|c|c|c|c|c|}
\hline \multicolumn{2}{|c|}{ Electricity Cost } & \multirow{2}{*}{$\begin{array}{c}\text { 2nd Trimester } 2013 \\
0.12981\end{array}$} & \multirow{2}{*}{$\begin{array}{c}\text { 3rd Trimester } 2013 \\
0.13209\end{array}$} & \multirow{2}{*}{$\begin{array}{c}\text { 4th Trimester } 2014 \\
0.13099\end{array}$} \\
\hline \multirow{4}{*}{ Energy $(€ /$ kWh $)$} & $<1800$ kWh/year & & & \\
\hline & $1800-2640 \mathrm{kWh} /$ year & 0.18523 & 0.18774 & 0.18949 \\
\hline & 2640-4440 kWh/year & 0.24893 & 0.25176 & 0.25729 \\
\hline & $>4440$ kWh/year & 0.29569 & 0.29852 & 0.30424 \\
\hline \multirow{2}{*}{\multicolumn{2}{|c|}{$\begin{array}{c}\text { Power }(€ / \mathrm{kW} / \text { year }) \\
\text { Fixed cost }(€ / \text { year })\end{array}$}} & 21.6050 & 21.6050 & 23.5386 \\
\hline & & 5.7374 & 5.7374 & 5.9570 \\
\hline
\end{tabular}

The economic analysis was performed also considering:

- the yearly degradation rate in the efficiency of the PV panels, set equal to $0.7 \%$ of the nominal initial value [91-95];

- $\quad$ the yearly maintenance and management costs, estimated to be $1 \%$ of the investment cost [1];

- $\quad$ the replacement of $1 \%$ of the PV panels every year and of all inverters every ten years [96-98];

- the insurance costs, varying from 184.00 to $334.00 €$, for PV systems with peak-power of $3 \mathrm{kWp}$ and $18 \mathrm{kWp}$ respectively;

- $\quad$ the FIT and premium listed in Table 1, for June 2013;

- the tax credit rates indicated in paragraph 2;

- a selling price of the PV electricity in Palermo of $0.103 € / \mathrm{kWh}$ and $0.079 € / \mathrm{kWh}$, for July 2013 and December 2014, respectively [99,100];

- a selling price of the PV electricity in Rome of $0.061 € / \mathrm{kWh}$ and $0.062 € / \mathrm{kWh}$, for July 2013 and December 2014, respectively [99,100];

- a selling price of the PV electricity in Milan of $0.062 € / \mathrm{kWh}$ and $0.061 € / \mathrm{kWh}$, for July 2013 and December 2014, respectively [99,100];

- the net gain in selling the exported PV electricity, evaluated charging an income tax of $38 \%, 41 \%$ and $43 \%$, which was estimated on the basis of the average income of the inhabitants of Palermo, Rome and Milan, respectively [101-103];

- a VAT rate of $10 \%$;

- the yearly increase in the price of electricity of 3.302\%, 3.291\% and 2.885\% for June 2013, July 2013 and December 2014, respectively, which were derived by the trend line calculated with the data issued by the AEEG for the previous 10 years [90];

- an average inflation rate of 1.983\%, 1.972\% and 1.706\% for June 2013, July 2013 and December 2014, respectively, obtained from the data issued by the Italian National Institute of Statistics for the previous 10 years, which were used to time-discount the costs during that time [104];

- a net discount rate current value of $4.230 \%, 4.296 \%$ and $2.795 \%$ for June 2013, July 2013 and December 2014, respectively, assumed equal to the interest paid by Italian long term public securities, which may be considered by the homeowners as an investment with a similar risk [105].

The NPV was calculated considering 16 slanted roof types and five flat roof types covering buildings with a number of storeys ranging from one to 11, which corresponds to 231 different calculations for each district. Considering that the calculus was repeated for each city and for various values of the utilization coefficient and percentage of shaded solar energy, the total calculated NPVs reach a number too large to be depicted in figures or tables. To illustrate the procedure, the data used to calculate the NPV of a PV system installed in Palermo in July 2013 on the roof type T2 of a building with two or five floors, assuming $c_{u}=0.4$ and a percentage of shaded solar energy of $10 \%$, are listed in Tables 10 and 11. 
Table 10. NPV calculation for Palermo in 2016, roof type T2, two-storey building.

\begin{tabular}{|c|c|c|c|c|c|c|c|c|c|c|c|}
\hline \multirow{2}{*}{ Year } & \multicolumn{6}{|c|}{ Disbursements ( $€ /$ Year) } & \multicolumn{4}{|c|}{ Revenues (€/Year) } & \multirow{2}{*}{$\begin{array}{c}\text { Net Cash Flow } \\
(€ / \text { Year })\end{array}$} \\
\hline & Installation & O\&M & Insurance & $\begin{array}{c}\text { Inverter } \\
\text { Substitution }\end{array}$ & $\begin{array}{c}\text { Panel } \\
\text { Substitution }\end{array}$ & Total & $\begin{array}{l}\text { Electricity } \\
\text { Bill Cut }\end{array}$ & $\begin{array}{c}\text { Tax } \\
\text { Deduction }\end{array}$ & $\begin{array}{l}\text { Exported } \\
\text { Electricity }\end{array}$ & Total & \\
\hline 0 & $15,612.47$ & - & - & - & - & $15,612.47$ & - & - & - & - & $-15,612.47$ \\
\hline 1 & - & 156.12 & 221.30 & - & 95.87 & 473.30 & 605.35 & 780.62 & 346.02 & 1731.99 & $-14,353.78$ \\
\hline 2 & - & 159.20 & 225.66 & - & 97.77 & 482.63 & 625.27 & 785.42 & 354.05 & 1764.74 & $-13,071.68$ \\
\hline 3 & - & 162.34 & 230.11 & - & 99.69 & 492.15 & 645.84 & 795.23 & 361.87 & 1802.94 & $-11,760.88$ \\
\hline 4 & - & 165.54 & 234.65 & - & 101.66 & 501.85 & 667.09 & 798.82 & 369.47 & 1835.39 & $-10,427.35$ \\
\hline 5 & - & 168.81 & 239.28 & - & 103.66 & 511.75 & 689.05 & 802.48 & 376.86 & 1868.38 & -9070.71 \\
\hline 6 & - & 172.14 & 244.00 & - & 105.71 & 521.84 & 711.72 & 806.21 & 384.03 & 1901.96 & -7690.58 \\
\hline 7 & - & 175.53 & 248.81 & - & 107.79 & 532.13 & 735.14 & 810.02 & 390.99 & 1936.15 & -6286.56 \\
\hline 8 & - & 178.99 & 253.71 & - & 109.92 & 542.62 & 759.33 & 813.90 & 397.74 & 1970.97 & -4858.21 \\
\hline 9 & - & 182.52 & 258.71 & - & 112.08 & 553.32 & 784.32 & 817.86 & 404.27 & 2006.44 & -3405.09 \\
\hline 10 & - & 186.12 & 263.82 & - & 114.29 & 564.23 & 810.12 & 821.89 & 410.59 & 2042.60 & -1926.71 \\
\hline 11 & - & 189.79 & 269.02 & 3605.62 & 116.55 & 4180.97 & 836.78 & 45.38 & 416.69 & 1298.86 & -4808.83 \\
\hline 12 & - & 193.53 & 274.32 & - & 118.84 & 586.70 & 864.32 & 174.59 & 422.58 & 1461.49 & -3934.04 \\
\hline 13 & - & 197.35 & 279.73 & - & 121.19 & 598.26 & 892.76 & 169.05 & 428.26 & 1490.07 & -3042.24 \\
\hline 14 & - & 201.24 & 285.25 & - & 123.58 & 610.06 & 922.14 & 169.82 & 433.72 & 1525.68 & -2126.62 \\
\hline 15 & - & 205.20 & 290.87 & - & 126.01 & 622.09 & 952.48 & 170.61 & 438.97 & 1562.06 & -1186.64 \\
\hline 16 & - & 209.25 & 296.60 & - & 128.50 & 634.35 & 983.82 & 171.42 & 444.00 & 1599.24 & -221.75 \\
\hline 17 & - & 213.38 & 302.45 & - & 131.03 & 646.86 & 1016.20 & 172.24 & 448.82 & 1637.26 & 768.64 \\
\hline 18 & - & 217.58 & 308.42 & - & 133.62 & 659.62 & 1049.64 & 173.07 & 453.43 & 1676.14 & 1785.17 \\
\hline 19 & - & 221.87 & 314.50 & - & 136.25 & 672.62 & 1084.17 & 173.93 & 457.82 & 1715.93 & 2828.47 \\
\hline 20 & - & 226.25 & 320.70 & - & 138.94 & 685.88 & 1119.85 & 174.80 & 462.00 & 1756.65 & 3899.24 \\
\hline \multicolumn{2}{|c|}{ City: Palermo } & \multicolumn{2}{|c|}{ Roof type: $\mathrm{T} 2$} & \multicolumn{2}{|c|}{ Number of floors: 2} & & & \multicolumn{3}{|c|}{ NPV at the 20th year $(€)$} & -2118.40 \\
\hline
\end{tabular}


Table 11. NPV calculation for Palermo in July 2013, roof type T2, five-storey building.

\begin{tabular}{|c|c|c|c|c|c|c|c|c|c|c|c|}
\hline \multirow[b]{2}{*}{ Year } & \multicolumn{6}{|c|}{ Disbursements (€/Year) } & \multicolumn{4}{|c|}{ Revenues ( $€ /$ Year) } & \multirow{2}{*}{$\begin{array}{l}\text { Net Cash Flow } \\
(€ / \text { Year })\end{array}$} \\
\hline & Installation & O\&M & Insurance & $\begin{array}{c}\text { Inverter } \\
\text { Substitution }\end{array}$ & $\begin{array}{c}\text { Panel } \\
\text { Substitution }\end{array}$ & Total & $\begin{array}{l}\text { Electricity } \\
\text { Bill Cut }\end{array}$ & $\begin{array}{c}\text { Tax } \\
\text { Deduction }\end{array}$ & $\begin{array}{l}\text { Exported } \\
\text { Electricity }\end{array}$ & Total & \\
\hline 0 & 6936.55 & - & - & - & - & 6936.55 & - & - & - & - & -6936.55 \\
\hline 1 & - & 69.37 & 182.25 & - & 35.95 & 287.57 & 605.35 & 346.83 & 55.84 & 1008.01 & -6216.10 \\
\hline 2 & - & 70.73 & 185.84 & - & 36.66 & 293.24 & 625.27 & 348.62 & 56.42 & 1030.31 & -5479.03 \\
\hline 3 & - & 72.13 & 189.51 & - & 37.38 & 299.02 & 645.84 & 352.33 & 56.92 & 1055.09 & -4722.95 \\
\hline 4 & - & 73.55 & 193.24 & - & 38.12 & 304.91 & 667.09 & 353.68 & 57.33 & 1078.11 & -3949.76 \\
\hline 5 & - & 75.00 & 197.05 & - & 38.87 & 310.93 & 689.05 & 355.05 & 57.67 & 1101.77 & -3158.92 \\
\hline 6 & - & 76.48 & 200.94 & - & 39.64 & 317.06 & 711.72 & 356.45 & 57.93 & 1126.10 & -2349.88 \\
\hline 7 & - & 77.99 & 204.90 & - & 40.42 & 323.31 & 735.14 & 357.88 & 58.11 & 1151.12 & -1522.06 \\
\hline 8 & - & 79.52 & 208.94 & - & 41.22 & 329.68 & 759.33 & 359.33 & 58.20 & 1176.87 & -674.88 \\
\hline 9 & - & 81.09 & 213.06 & - & 42.03 & 336.18 & 784.32 & 360.81 & 58.22 & 1203.35 & 192.29 \\
\hline 10 & - & 82.69 & 217.26 & - & 42.86 & 342.81 & 810.12 & 362.33 & 58.16 & 1230.61 & 1080.09 \\
\hline 11 & - & 84.32 & 221.54 & 1935.64 & 43.71 & 2285.21 & 836.78 & 17.04 & 58.02 & 911.84 & -293.28 \\
\hline 12 & - & 85.98 & 225.91 & - & 44.57 & 356.46 & 864.32 & 86.50 & 57.79 & 1008.61 & 358.87 \\
\hline 13 & - & 87.68 & 230.37 & - & 45.45 & 363.49 & 892.76 & 84.40 & 57.49 & 1034.65 & 1030.03 \\
\hline 14 & - & 89.41 & 234.91 & - & 46.34 & 370.66 & 922.14 & 84.69 & 57.10 & 1063.93 & 1723.30 \\
\hline 15 & - & 91.17 & 239.54 & - & 47.26 & 377.97 & 952.48 & 84.99 & 56.64 & 1094.11 & 2439.44 \\
\hline 16 & - & 92.97 & 244.26 & - & 48.19 & 385.42 & 983.82 & 85.29 & 56.10 & 1125.21 & 3179.23 \\
\hline 17 & - & 94.80 & 249.08 & - & 49.14 & 393.02 & 1016.20 & 85.60 & 55.47 & 1157.26 & 3943.48 \\
\hline 18 & - & 96.67 & 253.99 & - & 50.11 & 400.77 & 1049.64 & 85.91 & 54.77 & 1190.31 & 4733.02 \\
\hline 19 & - & 98.58 & 259.00 & - & 51.09 & 408.67 & 1084.17 & 86.23 & 53.98 & 1224.39 & 5548.74 \\
\hline 20 & - & 100.52 & 264.10 & - & 52.10 & 416.73 & 1119.85 & 86.56 & 53.12 & 1259.52 & 6391.53 \\
\hline \multicolumn{2}{|c|}{ City: Palermo } & \multicolumn{2}{|c|}{ Roof type: T2 } & \multicolumn{2}{|c|}{ Number of floors: 5} & & & \multicolumn{3}{|c|}{ NPV at the 20th year $(€)$} & 1954.94 \\
\hline
\end{tabular}


With reference to the data listed in Table 10, the PV system installed on the two-storey building presents a high installation cost, as the PV array can cover a large part of the available roof surface. Despite the revenues obtained from the exported electricity and the significant reduction in the electricity bills, such PV system has a negative NPV at the end of the evaluation period and therefore it is not considered economically viable. The array of the PV system installed on the five-storey building, whose data are listed in Table 11, uses only a part of the building roof as such surface is shared with the other four co-owners. Despite the PV system does not cover the entire energy demand of the household it results economically effective, as the NPV is positive at the end of the 20th year. It is realistic to suppose that only the PV systems that were considered economically convenient by homeowners would be really installed on the buildings. For this reason, in order to evaluate the effective coverage of the electricity demand of the district, the results obtained from the energy assessment have to be coupled with the results of the economic analysis.

\subsection{Results of the Energy and Economic Analysis}

Assuming that only economically convenient PV systems were installed, the coverage of the electricity demand of the districts was calculated by filtering out the electricity generated by the PV systems that have negative values of the NPV. Moreover, to take into account the possible mismatch between PV generation and consumption, the coverage of the electricity demand was calculated using the load match indexes of the analysed districts. Figures 9-11 show the values of the load match indexes obtained after filtering out the contribution of the PV systems with a negative NPV. Such values are the maximum ones because they were calculated assuming $c_{u}=1$ and omitting the shading effect of the obstructions. In the same figures the values of the gross energy cover factor calculated with Equation (1) are depicted.

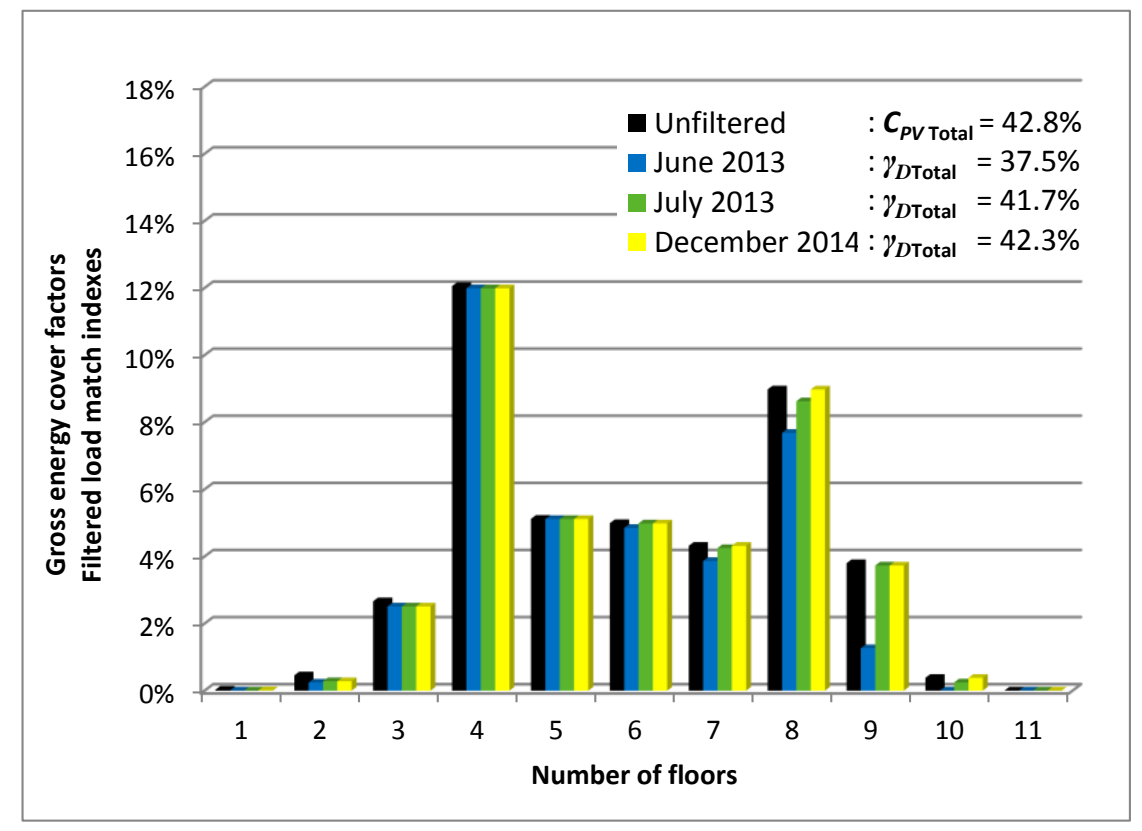

Figure 9. Yearly gross energy cover factors and filtered load match indexes for the whole district of Palermo versus the number of floors. 


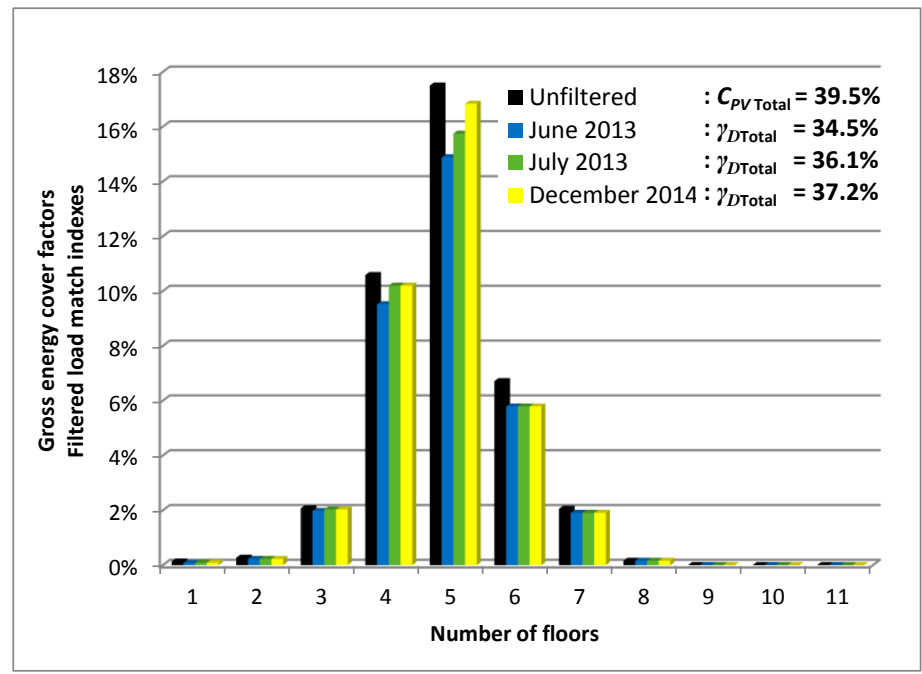

Figure 10. Yearly gross energy cover factors and filtered load match indexes for the whole district of Rome versus the number of floors.

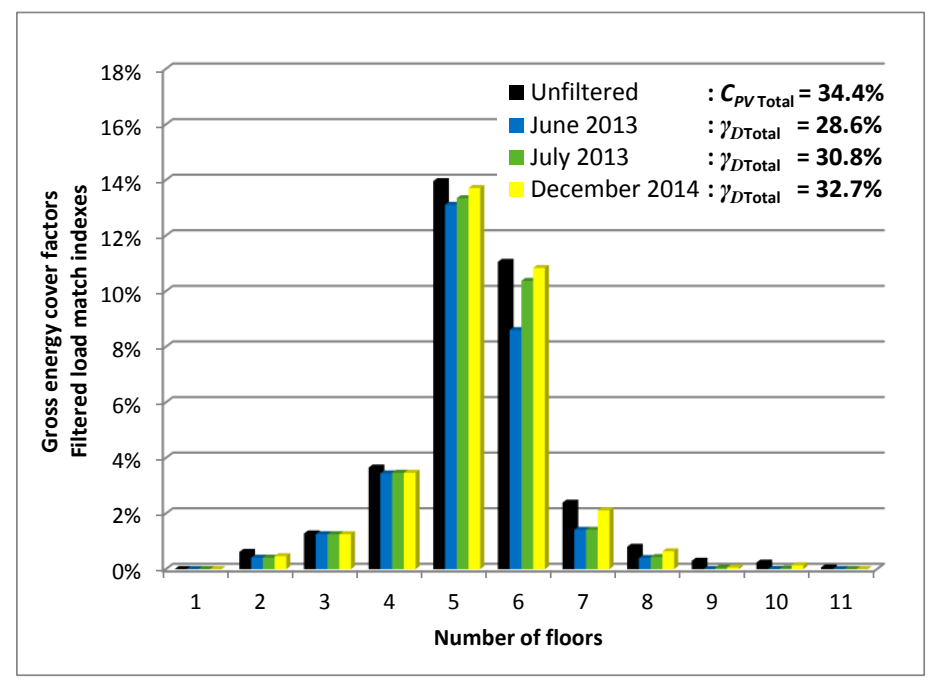

Figure 11. Yearly gross energy cover factors and filtered load match indexes for the whole district of Milan versus the number of floors.

The yearly filtered load match index for the district of Palermo is $37.5 \%$ in June 2013, which is the last month of the FIT scheme set by the 5th "Conto Energia", and 41.7\%, in July 2013, and 42.3\%, in December 2014, when the tax credits scheme was in force. In June 2013, $\gamma_{D}$ is $34.5 \%$ and $28.6 \%$ for the districts of Rome and Milan, respectively. The yearly filtered load match indexes for the district of Rome are equal to $36.1 \%$ and $37.2 \%$ in July 2013 and December 2014 respectively. In the same months, values of $\gamma_{D}$ equal to $30.8 \%$ and $32.7 \%$ are respectively calculated for the district of Milan. The contribution of the PV systems installed on tall buildings is quite small and tends to fade according to the number of floors. As a consequence, it is likely that smaller values of the coverage of the domestic electricity demand will be reached in the districts more recently built, where tall buildings are generally more frequent due to the modern use of reinforced concrete.

As it was predictable, the data filtering reduces the energy coverage of all cities. The effects are more evident considering the data calculated in June 2013 and, in particular, for the PV systems installed on the buildings with a greater number of floors in Palermo. Adversely, the data filtering marginally modifies the values of the load match indexes evaluated in July 2013 and December 2014. 
The difference between such months is negligible despite the fact that the PV systems installed in July 2013 were incentivised with a tax credit of $50 \%$ whereas only a tax credit of $40 \%$ supported the PV systems installed in December 2014. Figure 12 shows the global values of the filtered load match index before and after the change in the promoting policies.

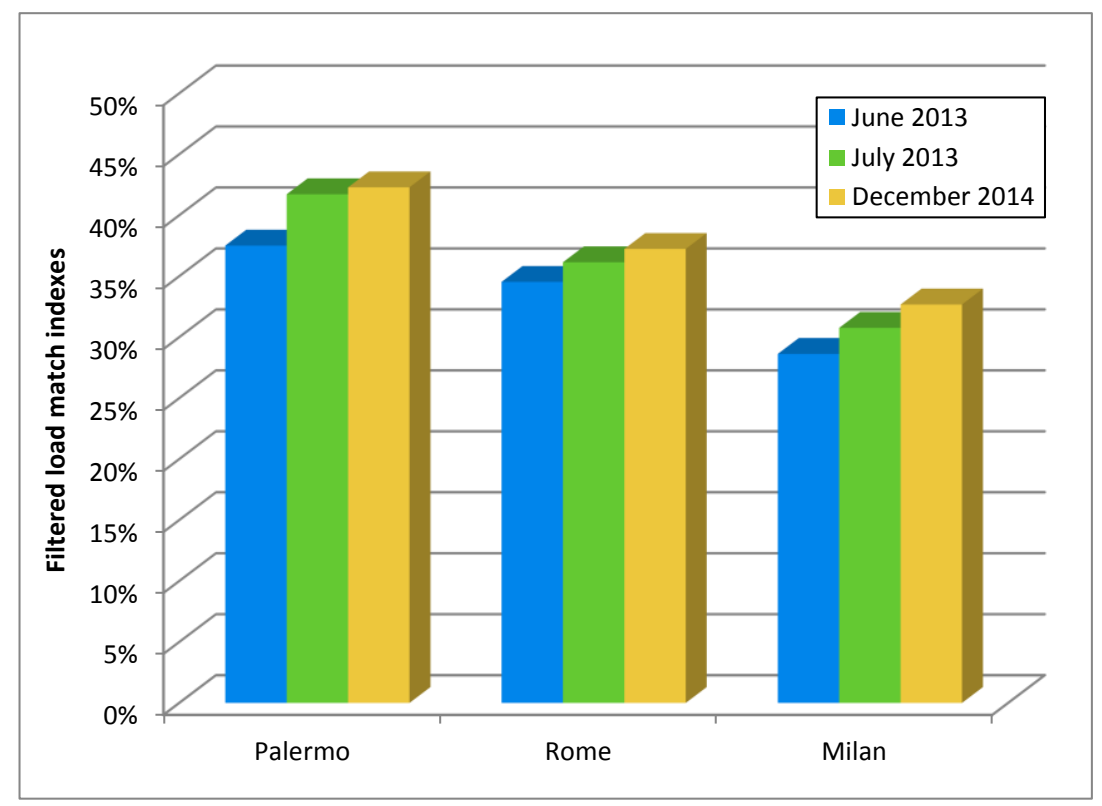

Figure 12. Filtered load match indexes for the whole districts of the analysed cities.

In December 2014, the electricity demand coverage of the PV systems in Milan, which benefit from the tax credit scheme, is up to $14.3 \%$ higher than the coverage calculated in June 2013, when the FIT scheme was still in force. The analogous increase in the electricity demand coverage is equal to $7.8 \%$ in Rome and $12.8 \%$ in Palermo. The direct comparison between the load match indexes shows the great significance of the economic analysis in evaluating the effects of the two different support policies. The gains for the reduced electricity bills and the sold electricity apart, the level of the economic convenience of PV systems largely depends on the incentives. The established values of the FITs are less effective than the tax credit rates to compensate the disbursements of PV investments.

The FIT scheme, which has been in force in Italy over many years, provided a premium proportional to the generated energy. Despite the de-escalation rates, which were applied to ratchet down the tariffs over the time, such direct monetary incentive was considered an attractive and efficient instrument to achieve an acceptable energy and economic return. It was expected that the change in the Italian policies for photovoltaics could reduce the interest in installing PV systems and induce the investors to choose other opportunities. On the contrary, the present study shows that the new tax credit scheme, which only allows taxpayers to reduce the amount of tax that they owe to the government, is very effective in assuring the energy demand coverage and enhancing the PV diffusion in Italy. Moreover, it can be observed that the policy context can hold the PV systems dissemination more than the natural potential of the considered location. Although the morphological conditions of the urban context, along with the energy and economic parameters, are relevant contributing factors for a successful integration of PV systems on the building rooftops, the adopted supporting schemes are of crucial importance to household or professional investors, who obviously prefer to invest in projects that provide a satisfactory return.

\section{Sensitivity Analysis}

The results presented in the previous section refer to a condition in which the available solar energy is completely harnessed by the producers, because no obstruction shadows the PV fields, 
and the electricity generated perfectly matches the energy demands of flats. Actually, such an ideal condition is quite far from the real operation of PV systems installed in densely urbanised districts in which, because both low and tall buildings are present, the PV arrays placed on the roofs of low buildings, which are the most effective in covering the electricity demand, may be very likely shadowed by the adjoining tall buildings. Moreover, the presence of an amount of mismatch between generation and consumption should be realistically considered because even the most meticulous householder may not be capable of using all the electricity generated by a PV system not equipped with batteries. The accurate assessment of the effects of both the PV array shadowing and the load mismatch would require a dynamic analysis of the PV systems based on numerous environmental and electrical parameters. It would be necessary to consider the instantaneous values of the solar irradiance, air temperature and velocity, which affect the current-voltage characteristics of the used PV panels, the value of the electrical load connected to the inverter, which influences the operation of the maximum power point tracking, and the shape, position and height of the surrounding buildings in order to check if the PV array may be shadowed by them. Moreover, because it is unlikely that the PV system results totally shadowed, the analysis of the electrical behaviour should consider the shading of each single PV panel, or even PV cells, because it is known that the global electrical performance of a PV array can be reduced by the malfunction of a single PV device. Even though the described analysis, which would require a large extent of reliable data and computations, was carried out considering the totality of the PV systems of the districts, the results would never have a general validity because some relevant information, such as the instantaneous values of the domestic electrical loads connected to each inverter, may be just supposed on the basis of hypothetical scenarios. In addition, the results would be valid only for the studied districts and such districts, even if selected to be representatives, are only a sample of the analysed cities.

For the above reasons, the assessment of the load mismatch and shading effects was carried out by means of a sensitivity analysis based on the available yearly data and information. The described results represent how the load mismatch and shading averagely affect the electricity coverage of the totality of the PV systems installed on the roofs of the analysed districts. The shading effects are evaluated using a shading coefficient that varies from zero (no shading) to $100 \%$ (no solar energy is collected). In Figures 13-18 the curves of the load match indexes versus the utilization coefficient, for some values of the shading coefficient, are depicted.

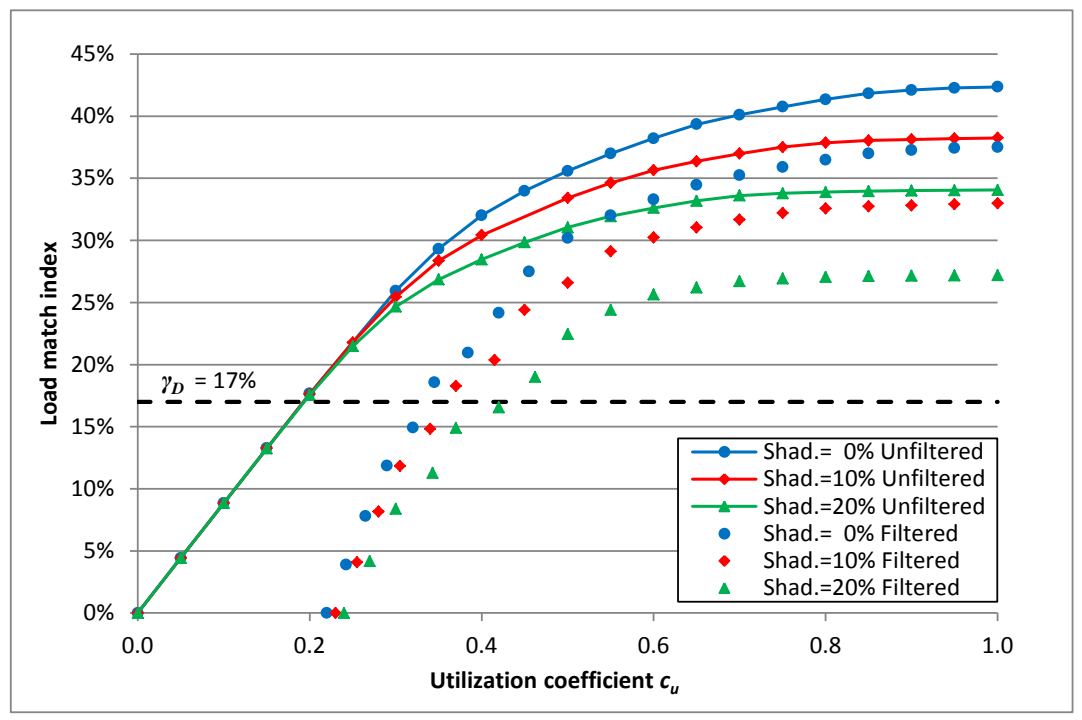

Figure 13. Yearly load match indexes for the whole district of Palermo in June 2013 versus the utilization coefficient. 


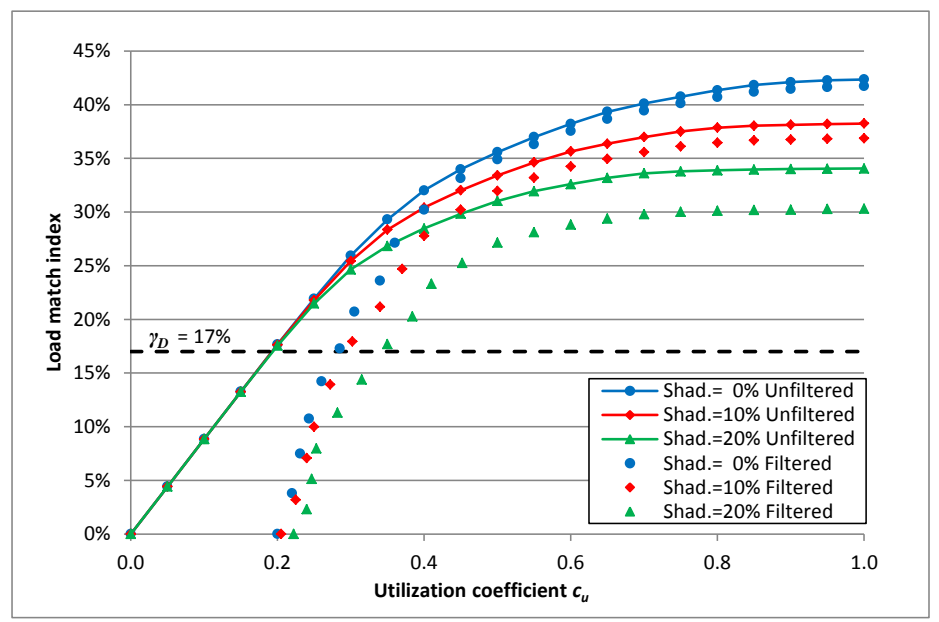

Figure 14. Yearly load match indexes for the whole district of Palermo in July 2013 versus the utilization coefficient.

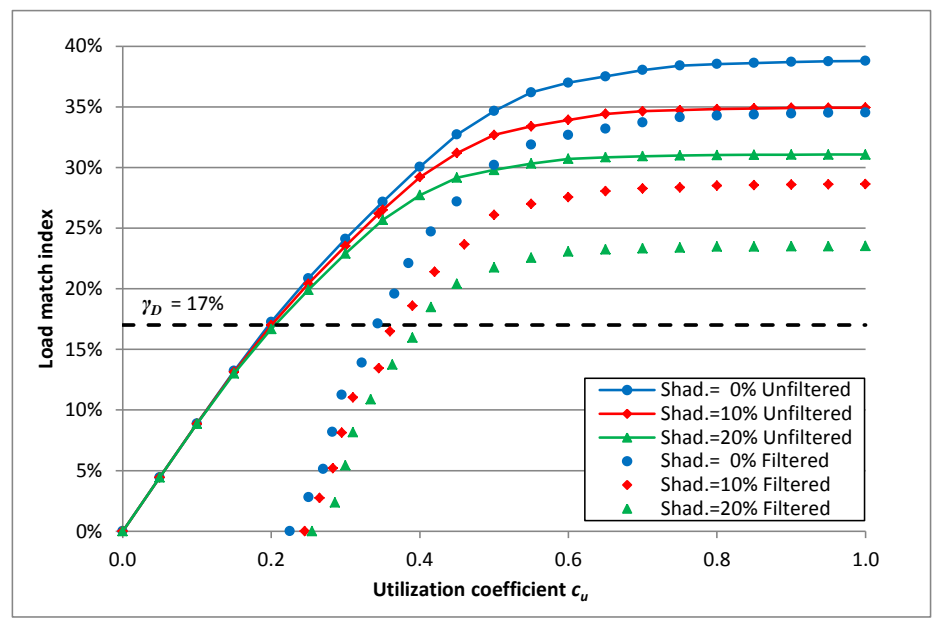

Figure 15. Yearly load match indexes for the whole district of Rome in June 2013 versus the utilization coefficient.

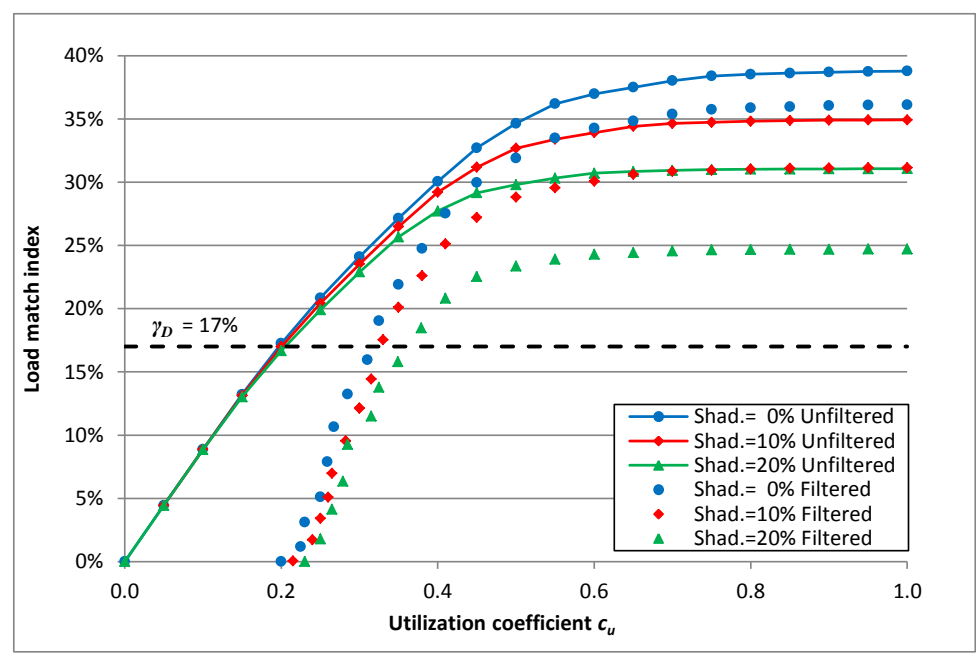

Figure 16. Yearly load match indexes for the whole district of Rome in July 2013 versus the utilization coefficient. 


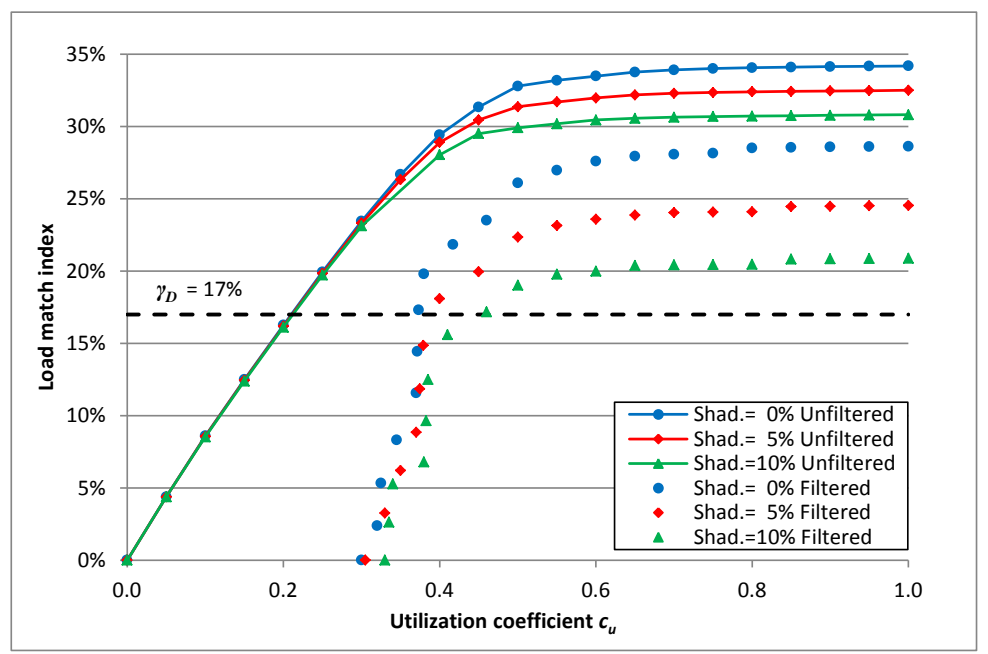

Figure 17. Yearly load match indexes for the whole district of Milan in June 2013 versus the utilization coefficient.

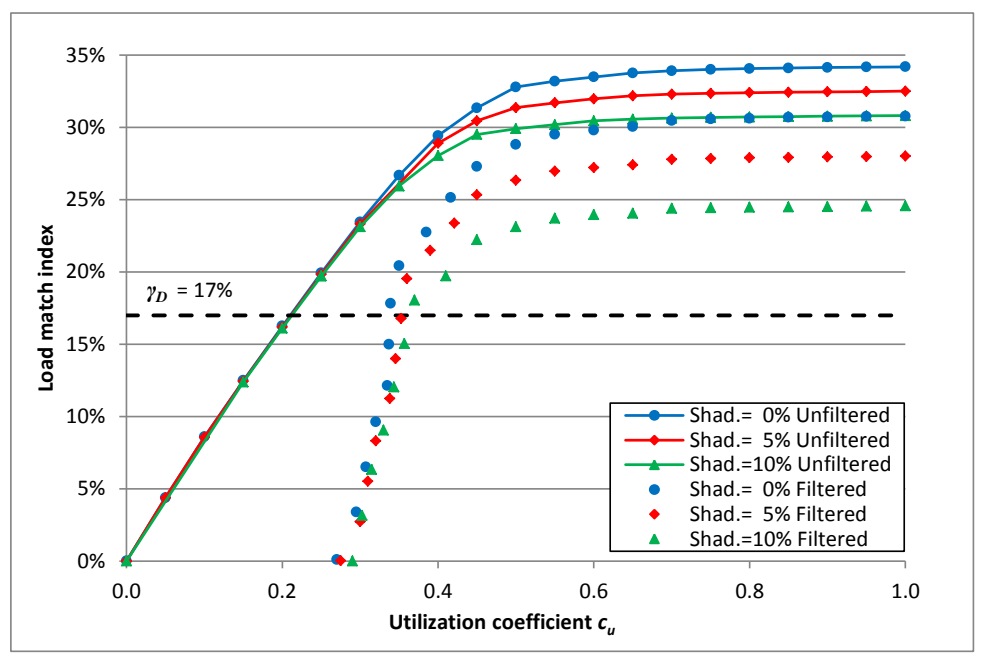

Figure 18. Yearly load match indexes for the whole district of Milan in July 2013 versus the utilization coefficient.

Both the unfiltered and filtered load match indexes are lower when the utilization coefficient is reduced. The reduction is obviously more evident for the filtered load match indexes because of the omission of the PV systems that have a negative value of the NPV. Comparing the data that refer to the same city, it is possible to appreciate that the curves of the filtered match index calculated in June 2013 are lower than the ones evaluated in July 2013; such behaviour becomes more evident by increasing the shading coefficient. The district of Milan results particularly affected by the shading coefficient; actually, the values of the load match index calculated with a shading coefficient of $10 \%$ are comparable with the data obtained for Palermo and Rome for a value of the shading coefficient of $20 \%$.

In the previous graphs also the lines for $\gamma_{D}$ of $17 \%$, which is the target value established by the Directive 2009/28/EC for Italy [106], are depicted. From the comparison with the calculated results, it is evident that the tax credits scheme, in force after June 2013, results more effective in keeping the load match index at values greater than the target value of $17 \%$. Such a conclusion is confirmed by the data shown in Figures 19-21, which refer to December 2014. 


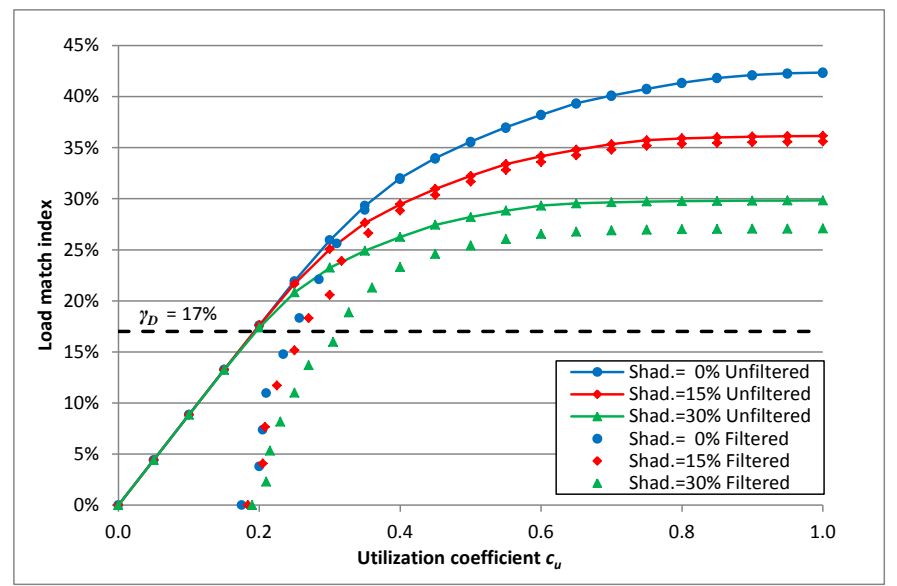

Figure 19. Yearly load match indexes for the whole district of Palermo in December 2014 versus the utilization coefficient.

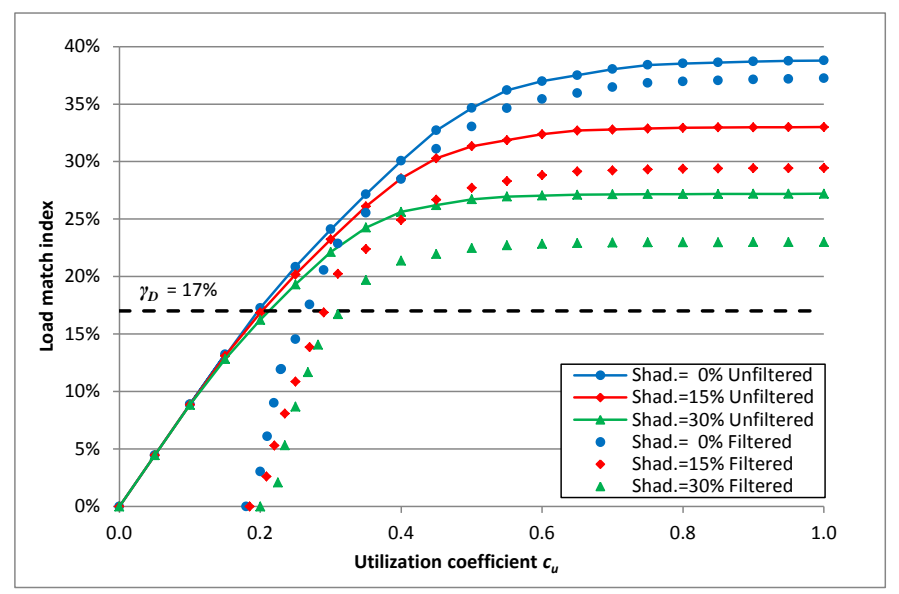

Figure 20. Yearly load match indexes for the whole district of Rome in December 2014 versus the utilization coefficient.

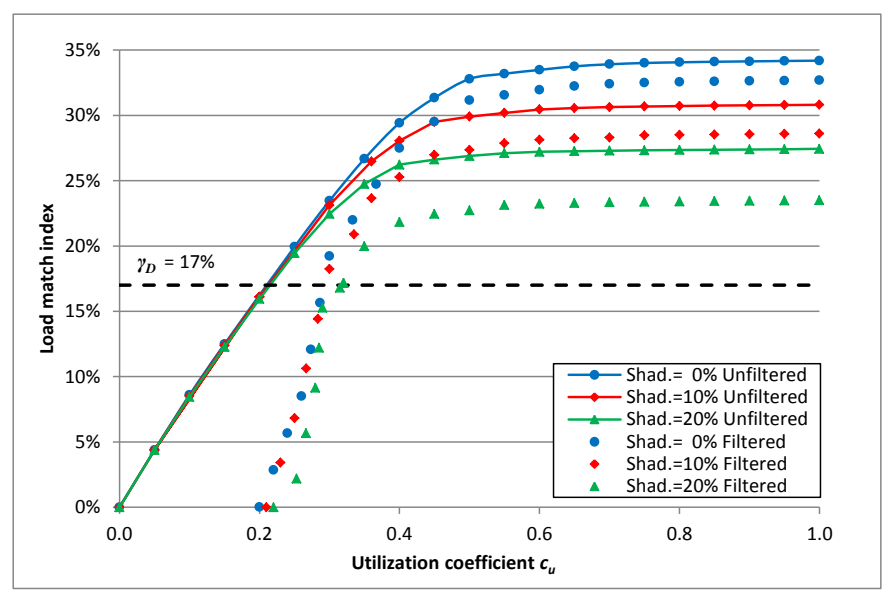

Figure 21. Yearly load match indexes for the whole district of Milan in December 2014 versus the utilization coefficient.

If no economic filtering of the data is considered, the values of $c_{u}$ in correspondence to which the load match index is equal to $17 \%$ seem almost unaffected by the percentage of shaded solar 
energy; moreover, such values are much smaller than the values obtained considering the economic profitability of the PV systems. As a consequence, one may erroneously infer that the presence of shading buildings is not an issue and that, even if about $80 \%$ of the generated electricity does not match household consumption, the target value established by the Directive 2009/28/EC can be reached for each city. The filtered data gives more realistic results that highlight the importance of the latitude, the shading coefficient and the presence of the load mismatch. Table 12 lists the values of the utilization coefficient for which the filtered load match index is equal to $17 \%$.

Table 12. Utilization coefficients at filtered $\gamma_{D}=17 \%$.

\begin{tabular}{cccccccc}
\hline \multirow{2}{*}{ City } & Month & \multicolumn{7}{c}{ Shading Coefficient } \\
\cline { 3 - 7 } & & $\mathbf{0 \%}$ & $\mathbf{5 \%}$ & $\mathbf{1 0 \%}$ & $\mathbf{1 5 \%}$ & $\mathbf{2 0} \%$ & $\mathbf{3 0} \%$ \\
\hline \multirow{3}{*}{ Palermo } & June 2013 & 0.334 & 0.340 & 0.359 & 0.392 & 0.428 & - \\
& July 2013 & 0.282 & 0.287 & 0.301 & 0.310 & 0.328 & 0.400 \\
& December 2014 & 0.244 & 0.247 & 0.251 & 0.256 & 0.266 & 0.318 \\
\hline \multirow{3}{*}{ Rome } & June 2013 & 0.343 & 0.348 & 0.367 & 0.386 & 0.400 & - \\
& July 2013 & 0.315 & 0.326 & 0.328 & 0.337 & 0.362 & 0.398 \\
& December 2014 & 0.260 & 0.265 & 0.267 & 0.291 & 0.295 & 0.314 \\
\hline \multirow{3}{*}{ Milan } & June 2013 & 0.373 & 0.393 & 0.454 & - & - & - \\
& July 2013 & 0.339 & 0.343 & 0.352 & 0.390 & 0.455 & - \\
& December 2014 & 0.275 & 0.278 & 0.285 & 0.290 & 0.318 & - \\
\hline
\end{tabular}

For a fixed percentage of shaded solar energy, the coverage target set for Italy by the Directive $2009 / 28 / E C$ can be met only if values of the utilization coefficient grater of the threshold data in Table 10 are achieved. When the listed data are small, the householders are allowed a larger flexibility in using their domestic appliances because a greater amount of mismatch between PV generation and household consumption is tolerated without affecting the energy performance of the districts. It can be observed that the tax credits scheme is always more effective than the FIT scheme and its validity tends to increase further in time. Actually, the target value, which cannot be reached in Milan in 2013 with a shading coefficient of $15 \%$, is obtained in December 2014 if at least $71.0 \%$ of generated electricity is consumed by the household. Using the data of Table 12, similar observations can be made for the cities of Palermo and Rome.

On the basis of the presented results, it is possible to claim that, if the future values of the tax credits will be wisely fixed considering the current costs of PV devices, the recent Italian promoting policy will be able to adequately support the diffusion of domestic PV systems in densely urbanised areas. The effectiveness of the promoting policy would increase further if the values of the tax credits were arranged to compensate the effects of the latitude on the solar energy available in the various geographical areas of Italy.

\section{Conclusions}

A study on the electrical coverage of grid-connected rooftop PV systems was developed with the aim to evaluate the effectiveness of the energy strategies adopted over the 2013-2014 period: (1) the FIT mechanism that has guaranteed set prices for both generated electricity provided to the grid and self-consumed electricity; (2) the present tax credit scheme that, in contrast to the FIT program, does not include a remuneration, but directly allows the PV system owners to reduce their tax liability.

The approach combines the annual data of PV generation and electricity consumptions with a detailed architectural analysis of three Italian districts. The roof morphology, orientation, tilt and available surface for each householder, shading effects and load mismatch were considered. The results of the energy analysis were filtered by an economic analysis that included all costs (investment, insurance, replacement, maintenance and management costs) and benefits (FIT and premium on the self-consumed electricity, percentage of tax credit, reduced electricity bills, profits for sold electricity) of each PV system over a period of 20 years. The results show a significant reduction in the energy cover factors when, as it can be realistically assumed, only the energy produced by the 
economically advantageous PV systems is considered. The comparison between the FIT policy at the end of the supporting program (June 2013) and the tax credits scheme in December 2014 highlighted an increase in the electrical coverage from $37.5 \%, 34.5 \%$ and $28.6 \%$ to $42.3 \%, 37.2 \%$ and $32.7 \%$ for the districts in Palermo, Rome and Milan, respectively.

The results denote the major effectiveness of the energy policy based on the tax credits especially when solar energy shading and mismatch between PV generation and household consumption are considered. By means of a sensitivity analysis, the role of the shading and utilization coefficients, which respectively indicate the lack of solar energy, due to the surrounding buildings, and the mismatch between electricity generation and consumption, was considered. Aiming to assess the fulfilment of the target set for Italy by the Directive 2009/28/EC, the values of the utilization and shading coefficients, which allow $17 \%$ of the electrical coverage demand by renewable sources, were calculated. The presented study underlines how the results are significantly influenced by the latitude of the analysed districts. For this reason it would be desirable that the Italian government promoted supporting measures that were sensitive to the geographic position in order to compensate the penalizing effects of the latitude and reach the most homogeneous diffusion of the PV systems in each region of national territory.

Author Contributions: Aldo Orioli and Alessandra Di Gangi conceived and designed the methodology; Aldo Orioli and Vincenzo Franzitta performed the analysis; Alessandra Di Gangi and Ferdinando Foresta carried out the architectural analysis; Vincenzo Franzitta analyzed the data; Aldo Orioli and Alessandra Di Gangi wrote the paper.

Conflicts of Interest: The authors declare no conflict of interest.

\section{Nomenclature}

\begin{tabular}{|c|c|}
\hline$C_{P V}$ & gross energy cover factor of the district $(\%)$ \\
\hline$C F_{t}$ & cash flow at the generic $t$-th year $(€)$ \\
\hline$c_{u}$ & utilization coefficient $c_{u}$ \\
\hline$C_{0}$ & initial investment cost $(€)$ \\
\hline$D_{\text {Day }}$ & day-time yearly electricity demand of the standard flat $(\mathrm{kWh})$ \\
\hline$D_{\text {Day }, j}$ & day-time yearly electricity demand of the generic $j$-th PV system $(\mathrm{kWh})$ \\
\hline$D_{j}^{*}$ & yearly electricity demand of the generic $j$-th PV system $(\mathrm{kWh})$ \\
\hline$D_{j}$ & $\begin{array}{l}\text { electricity demand of the generic } j \text {-th PV system during the generic } i \text {-th time } \\
\text { interval }(\mathrm{kWh})\end{array}$ \\
\hline$D_{\text {Match }, j}$ & matched yearly energy demand of the generic $j$-th PV system (kWh) \\
\hline$D_{\text {Mism, } j}$ & mismatched yearly energy demand of the generic $j$-th PV system $(\mathrm{kWh})$ \\
\hline$D_{\text {Night }, j}$ & night-time yearly electricity demand of the generic $j$-th PV system $(\mathrm{kWh})$ \\
\hline$D_{\text {Night }}$ & night-time yearly electricity demand of the standard flat $(\mathrm{kWh})$ \\
\hline$D_{\text {Total }}$ & yearly electricity demand of the district (kWh) \\
\hline$E_{P V}$ & electricity generated by the totality of installed PV system $(\mathrm{kWh})$ \\
\hline$E_{P V, j}^{*}$ & yearly electricity produced by the generic $j$-th PV system $(\mathrm{kWh})$ \\
\hline$E_{P V, j}$ & $\begin{array}{l}\text { electricity generated by the generic } j \text {-th PV system during the generic } i \text {-th time } \\
\text { interval }(\mathrm{kWh})\end{array}$ \\
\hline$E_{P V l o a d}^{*}$ & yearly electricity supplied to the load by the generic $j$-th PV system $(\mathrm{kWh})$ \\
\hline & discount rate $(\%)$ \\
\hline$N$ & number of samples in the evaluation period \\
\hline$N_{P V}$ & number of PV systems \\
\hline NPV & net present value $(€)$ \\
\hline$N_{t}$ & life time of the investment (years) \\
\hline$t$ & generic $t$-th year \\
\hline$\gamma_{D}$ & load match index of the district (\%) \\
\hline
\end{tabular}




\section{References}

1. Zahedi, A. Development of an economical model to determine an appropriate feed-in tariff for grid-connected solar PV electricity in all states of Australia. Renew. Sustain. Energy Rev. 2008, 13, 871-878. [CrossRef]

2. Poullikkas, A. Parametric cost-benefit analysis for the installation of photovoltaic parks in the island of Cyprus. Energy Policy 2009, 37, 3673-3680. [CrossRef]

3. Campoccia, A.; Dusonchet, L.; Telaretti, E.; Zizzo, G. Comparative analysis of different supporting measures for the production of electrical energy by solar PV and Wind systems: Four representative European cases. Sol. Energy 2009, 83, 287-297. [CrossRef]

4. Dusonchet, L.; Telaretti, E. Economic analysis of different supporting policies for the production of electrical energy by solar photovoltaics in western European Union countries. Energy Policy 2010, 38, 3297-3308. [CrossRef]

5. Dusonchet, L.; Telaretti, E. Economic analysis of different supporting policies for the production of electrical energy by solar photovoltaics in eastern European Union countries. Energy Policy 2010, 38, 4011-4020. [CrossRef]

6. Burns, J.E.; Kang, J. Comparative economic analysis of supporting policies for residential solar PV in the United States: Solar Renewable Energy Credit (SREC) potential. Energy Policy 2012, 44, 217-225. [CrossRef]

7. Yamamoto, Y. Pricing electricity from residential photovoltaic systems: A comparison of feed-in tariffs, net metering, and net purchase and sale. Sol. Energy 2012, 86, 2678-2685. [CrossRef]

8. Orioli, A.; Di Gangi, A. The recent change in the Italian policies for photovoltaics: Effects on the payback period and levelized cost of electricity of grid-connected photovoltaic systems installed in urban contexts. Energy 2015, 93, 1989-2005. [CrossRef]

9. Sivaraman, D.; Horne, R.E. Regulatory potential for increasing small scale grid connected photovoltaic (PV) deployment in Australia. Energy Policy 2011, 39, 586-595. [CrossRef]

10. Al-Badi, A.H.; Albadi, M.H.; Al-Lawati, A.M.; Malik, A.S. Economic perspective of PV electricity in Oman. Energy 2011, 36, 226-232. [CrossRef]

11. Solangi, K.H.; Islam, M.R.; Saidur, R.; Rahim, N.A.; Fayaz, H. A review on global solar energy policy. Renew. Sustain. Energy Rev. 2011, 15, 2149-2163. [CrossRef]

12. Deshmukh, R.; Bharvirkar, R.; Gambhir, A.; Phadke, A. Changing Sunshine: Analyzing the dynamics of solar electricity policies in the global context. Renew. Sustain. Energy Rev. 2012, 16, 5188-5198. [CrossRef]

13. Celik, A.N. Present status of photovoltaic energy in Turkey and life cycle techno-economic analysis of a grid-connected photovoltaic-house. Renew. Sustain. Energy Rev. 2006, 10, 370-387. [CrossRef]

14. Stritih, U.; Zupan, G.; Butala, V. Review of green electricity production in Slovenia. Renew. Sustain. Energy Rev. 2007, 11, 2201-2208. [CrossRef]

15. Danchev, S.; Maniatis, G.; Tsakanifas, A. Returns on investment in electricity producing photovoltaic systems under de-escalating feed-in-tariffs: The case of Greece. Renew. Sustain. Energy Rev. 2009, 14, 500-505. [CrossRef]

16. Papadopoulos, A.M.; Karteris, M.M. An assessment of the Greek incentives scheme for photovoltaics. Energy Policy 2009, 37, 1945-1952. [CrossRef]

17. Lüthi, S. Effective deployment of photovoltaics in the Mediterranean countries: Balancing policy risk and return. Sol. Energy 2010, 84, 1059-1071. [CrossRef]

18. Rigter, J.; Vidican, G. Cost and optimal feed-in-tariff for small scale photovoltaic systems in China. Energy Policy 2010, 38, 6989-7000. [CrossRef]

19. Couture, T.; Gagnon, Y. An analysis of feed-in tariff remuneration models: Implications for renewable energy investment. Energy Policy 2010, 38, 955-965. [CrossRef]

20. Dinçer, F. The analysis on photovoltaic electricity generation status, potential and policies of the leading countries in solar energy. Renew. Sustain. Energy Rev. 2011, 15, 713-720. [CrossRef]

21. Sarasa-Maestro, C.J.; Dufo-López, R.; Bernal-Agustín, J.L. Photovoltaic remuneration policies in the European Union. Energy Policy 2013, 55, 317-328. [CrossRef]

22. Campoccia, A.; Dusonchet, L.; Telaretti, E.; Zizzo, G. An analysis of feed'in tariffs for solar PV in six representative countries of the European Union. Sol. Energy 2014, 107, 530-542. [CrossRef]

23. Di Dio, V.; Favuzza, S.; La Cascia, D.; Massaro, F.; Zizzo, G. Critical assessment of support for the evolution of photovoltaics and feed-in tariff(s) in Italy. Sustain. Energy Technol. Assess. 2015, 9, 95-104. [CrossRef] 
24. Rapporti Statistici. Gestore Servizi Energetici-GSE S.p.A. Available online: http://www.gse.it/it/ Statistiche/RapportiStatistici/Pagine/default.aspx (accessed on 9 November 2016).

25. Rapporti Mensili. Terna S.p.A. Available online: http://www.terna.it/default/Home/SISTEMA_ ELETTRICO/dispacciamento/dati_esercizio/rapporto_mensile.aspx (accessed on 9 November 2016).

26. Decreto Ministeriale 16 marzo 2001-Programma Tetti Fotovoltaici. Available online: http://www. minambiente.it/pagina/decreto-ministeriale-16-marzo-2001-programma-tetti-fotovoltaici (accessed on 9 November 2016).

27. European Parliament, Council of the European Union. Directive 2001/77/EC of the European Parliament and of the Council on the Promotion of Electricity Produced from Renewable Energy Sources in the Internal Electricity Market; European Parliament, Council of the European Union: Bruselles, Belgium, 27 September 2001.

28. Decreto Ministeriale 28 luglio 2005-Criteri per L'incentivazione Della Produzione di Energia Elettrica Mediante Conversione Fotovoltaica Della Fonte Solare. Available online: http:/ /www.ambientediritto.it/ Legislazione/Energia/2005/dm\%2028lug2005.htm (accessed on 9 November 2016).

29. Decreto Ministeriale 6 Febbraio 2006-Criteri per L'incentivazione Della Produzione di Energia Elettrica Mediante Conversione Fotovoltaica Della Fonte Solare-Dlgs 387/2003—Modifica DM 28 Luglio 2005. Available online: http://www.tuttocamere.it/files/attivita/2006_2_6.pdf (accessed on 9 November 2016).

30. Decreto Ministeriale 19 Febbraio 2007-Criteri e Modalità per Incentivare la Produzione di Energia Elettrica Mediante Conversione Fotovoltaica Della Fonte Solare, in Attuazione Dell'articolo 7 del Decreto Legislativo 29 Dicembre 2003, n. 387. Available online: http://www.regione.toscana.it/documents/10180/24000/ DM19022007_19feb/c67e9d64-d27a-487e-baf3-070b194100eb (accessed on 9 November 2016).

31. AEEG-Autorità per l'Energia Elettrica, il Gas e il Sistema Idrico. Delibera ARG/elt 74/08. Testo Integrato Delle Modalità e Delle Condizioni Tecnico-Economiche per lo Scambio sul Posto (TISP). Available online: http://www.autorita.energia.it/it/docs/08/074--08arg.htm (accessed on 9 November 2016).

32. Decreto Ministeriale 6 agosto 2010-Incentivazione Della Produzione di Energia Elettrica Mediante Conversione Fotovoltaica Della Fonte Solare. Available online: http://energia.regione.emilia-romagna. it/entra-in-regione/norme-e-atti-amministrativi/fonti-rinnovabili/nazionale/decreto $\% 20 \mathrm{ministeriale} \%$ 206\%20\%20agosto\%202010.pdf (accessed on 9 November 2016).

33. Decreto Ministeriale 5 maggio 2011-Incentivazione Della Produzione di Energia Elettrica da Impianti Solari Fotovoltaici. Available online: http://www.gazzettaufficiale.it/eli/id/2011/05/12/11A06083/sg (accessed on 9 November 2016).

34. Decreto Ministeriale 5 luglio 2012-Attuazione dell'art. 25 del Decreto Legislativo 3 Marzo 2011, n. 28, Recante Incentivazione Della Produzione di Energia Elettrica da Impianti Solari Fotovoltaici (c.d. Quinto Conto Energia). Available online: http://www.ilsole24ore.com/pdf2010/SoleOnLine5/_Oggetti_Correlati/ Documenti/Norme\%20e\%20Tributi/2012/07/guida-incentivi-fotovoltaico/Dm_5_luglio_2012.pdf (accessed on 9 November 2016).

35. Decreto Legge 83del 22.6.2012-Misure Urgenti per la Crescita del Paese, con l'art.11 “Detrazioni per Interventi di Ristrutturazione e di Efficientamento Energetico". Available online: http:/ /www.studiocataldi. it/normativa/decreto-sviluppo-giugno-2012/ (accessed on 9 November 2016).

36. Decreto Legge 63del 4.6.2013-Disposizioni Urgenti per il Recepimento Della Direttiva 2010/31/UE del Parlamento Europeo e del Consiglio del 19 Maggio 2010, Sulla Prestazione Energetica Nell'edilizia Per la Definizione Delle Procedure D'infrazione Avviate Dalla Commissione Europea, Nonchè Altre Disposizioni in Materia di Coesione Sociale. Available online: http://www.google.com.hk/url?sa=t\&rct=j\&q=\&esrc= s\&source=web\&cd=1\&ved=0ahUKEwj84tPz5ZrQAhUJF5QKHenRCrkQFggcMAA\&url=http \%3A \%2F\% 2Fwww.periti-industriali-reggioemilia.it\%2FPublic\%2FAllegati\%2FNews\%2Fopificium_news24_12_2013. pdf\&usg=AFQjCNGCXsfYON03VQqGOK-eQeFogQTrpw (accessed on 9 November 2016).

37. Legge 147 del 27.12.2013-Disposizioni per la Formazione del Bilancio Annuale e Pluriennale Dello Stato (Legge di Stabilità 2014). Available online: http://www.gazzettaufficiale.it/eli/id/2013/12/27/13G00191/ sg (accessed on 9 November 2016).

38. Hofierka, J.; Kaňuk, J. Assessment of photovoltaic potential in urban areas using open-source solar radiation tools. Renew. Energy 2009, 34, 2206-2214. [CrossRef]

39. Vardimon, R. Assessment of the potential for distributed photovoltaic electricity production in Israel. Renew. Energy 2011, 36, 591-594. [CrossRef] 
40. Bergamasco, L.; Asinari, P. Scalable methodology for the photovoltaic solar energy potential assessment based on available roof surface area: Further improvements by ortho-image analysis and application to Turin (Italy). Sol. Energy 2011, 85, 2741-2756. [CrossRef]

41. Brito, M.C.; Gomes, N.; Santos, T.; Tenedório, J.A. Photovoltaic potential in a Lisbon suburb using LiDAR data. Sol. Energy 2012, 86, 283-288. [CrossRef]

42. Redweik, P.; Catita, C.; Brito, M. Solar energy potential on roofs and facades in an urban landscape. Sol. Energy 2013, 97, 332-341. [CrossRef]

43. Santos, T.; Gomes, N.; Freire, S.; Brito, M.C.; Santos, L.; Tenedório, J.A. Applications of solar mapping in the urban environment. Appl. Geogr. 2014, 51, 48-57. [CrossRef]

44. Amado, M.; Poggi, F. Towards solar urban planning: A new step for better energy performance. Energy Procedia 2012, 30, 1261-1273. [CrossRef]

45. Amado, M.; Poggi, F. Solar urban planning: A parametric approach. Energy Procedia 2014, 48, 1539-1548. [CrossRef]

46. Kodysh, J.B.; Omitaomu, O.A.; Bhaduri, B.L.; Neish, B.S. Methodology for estimating solar potential on multiple building rooftops for photovoltaic systems. Sustain. Cities Soc. 2013, 8, 31-41. [CrossRef]

47. Esclapés, J.; Ferreiro, I.; Piera, J.; Teller, J. A method to evaluate the adaptability of photovoltaic energy on urban façades. Sol. Energy 2014, 105, 414-427. [CrossRef]

48. Klironomos, P.G.; Vokas, G.A.; Kaldellis, J.K. Potential of building integrated photovoltaic systems (BIPV): Study on the Oinofyta Viotias industrial buildings zone. In Proceedings of the 8th Mediterranean Conference on Power Generation, Transmission, Distribution and Energy Conversion (MEDPOWER 2012), Cagliari, Italy, 1-3 October 2012; pp. 1-6.

49. Portolan dos Santos, I.; Rüther, R. The potential of building-integrated (BIPV) and building-applied photovoltaics (BAPV) in single-family, urban residences at low latitudes in Brazil. Energy Build. 2012, 50, 290-297. [CrossRef]

50. Choi, Y.; Rayl, J.; Tammineedi, C.; Brownson, J.R.S. PV Analyst: Coupling ArcGIS with TRNSYS to assess distributed photovoltaic potential in urban areas. Sol. Energy 2011, 85, 2924-2939. [CrossRef]

51. Singh, R.; Banerjee, R. Estimation of roof-top photovoltaic potential using satellite imagery and GIS. In Proceedings of the IEEE 39th Photovoltaic Specialists Conference (PVSC), Tampa, FL, USA, 16-21 June 2013; pp. 2343-2347.

52. Schwarz, H.; Ying, S. Urban photovoltaic potential. In Proceedings of the 9th International Conference on Environment and Electrical Engineering (EEEIC), Prague, Czech Republic, 16-19 May 2010; pp. $26-28$.

53. Latif, Z.A.; Zaki, N.A.M.; Salleh, S.A. GIS-based estimation of rooftop solar photovoltaic potential using LiDAR. In Proceedings of the IEEE 8th International Colloquium on Signal Processing and its Applications (CSPA), Malacca, Malaysia, 23-25 March 2012; pp. 388-392.

54. Stoll, B.L.; Smith, T.A.; Deinert, M.R. Potential for rooftop photovoltaics in Tokyo to replace nuclear capacity. Environ. Res. Lett. 2013, 8, 1-9. [CrossRef]

55. Strzalka, A.; Alam, N.; Duminil, E.; Coors, V.; Eicker, U. Large scale integration of photovoltaics in cities. Appl. Energy 2012, 93, 413-421. [CrossRef]

56. Araya-Muñoz, D.; Carvajal, D.; Sáez-Carreño, A.; Bensaid, S.; Soto-Márquez, E. Assessing the solar potential of roofs in Valparaíso (Chile). Energy Build. 2014, 69, 62-73. [CrossRef]

57. Talavera, D.L.; de la Casa, J.; Muñoz-Cerón, E.; Almonacid, G. Grid parity and self-consumption with photovoltaic systems under the present regulatory framework in Spain: The case of the University of Jaén Campus. Renew. Sustain. Energy Rev. 2014, 33, 752-771. [CrossRef]

58. Cellura, M.; Di Gangi, A.; Longo, S.; Orioli, A. Photovoltaic electricity scenario analysis in urban context: An Italian case study. Renew. Sustain. Energy Rev. 2012, 16, 2041-2052. [CrossRef]

59. Guida Alla Realizzazione di Sistemi di Generazione Fotovoltaica Collegati alle Reti Elettriche di Media e Bassa Tensione; Norma CEI 82-25; Comitato Elettrotecnico Italiano: Milano, Italy, 2010.

60. PVsyst. Software for Photovoltaic Systems, Bât. D7, Route de Drize CH-1227 Carouge Switzerland; University of Geneva ISE e Group Energy, FOREL Battelle: Columbus, OH, USA, 2010.

61. SMA Solar Technology AG. Available online: http://www.sma.de/en/products/solarinverters/sunny-boy15--25.html\#Downloads-187499 (accessed on 9 November 2016).

62. SMA America Inc. Available online: http://www.sma-america.com/products/solarinverters/sunny-boy30-us-38-us-50-us-60-us-70-us-77-us.html\#Downloads-207158 (accessed on 9 November 2016). 
63. SMA America Inc. Available online: http://www.sma-america.com/partners/knowledgebase/optitracglobal-peak.html (accessed on 9 November 2016).

64. Orioli, A.; Di Gangi, A. Effects of the Italian financial crisis on the photovoltaic dissemination in a southern city. Energy 2013, 62, 173-184. [CrossRef]

65. Orioli, A.; Di Gangi, A. Review of the energy and economic parameters involved in the effectiveness of grid-connected PV systems installed in multi-storey buildings. Appl. Energy 2014, 113, 955-969. [CrossRef]

66. Dati Statistici Sull'energia Elettrica in Italia. Terna S.p.A. Available online: http://www.terna.it/default/ Home/SISTEMA_ELETTRICO/statistiche/dati_statistici.aspx (accessed on 9 November 2016).

67. Dati Statistici Istat: Popolazione residente-Censimento 2011-Superficie Delle Abitazioni Occupate da Persone Residenti. Istat. Italian National Institute of Statistics. Available online: http://daticensimentopopolazione.istat.it/ (accessed on 9 November 2016).

68. Commission of the European Communities. Demand-Side Management, End-Use Metring Campaign in 400 Households of the European Community, Assessment of the Potential Electricity Savings; Project EURECO; Commission of the European Communities: Brussels, Belgium, 2002.

69. End-use Efficiency Research Group (eERG). MICENE Misure dei Consumi di Energia Elettrica in 110 Abitazioni Italiane, Curve di Carico dei Principali Elettrodomestici e Egli Apparecchi di Illuminazione; Politecnico di Milano: Milano, Italy, 2004.

70. Institute for Environment and Sustainability (IES); Joint Research Centre-European Commission (JRC). Electricity Consumption and Efficiency Trends in the Enlarged European Union; Status Report; Joint Research Centre, European Commission: Ispra, Italy, 2006.

71. International Energy Agency (IEA). Final Report of Annex 42-Energy Conservation in Buildings and Community System Programme; International Energy Agency: Paris, France, 2008.

72. Paatero, J.V.; Lund, P.D. Effects of large-scale photovoltaic power integration on electricity distribution networks. Renew. Energy 2007, 32, 216-234. [CrossRef]

73. Denholm, P.; Margolis, R.M. Evaluating the limits of solar photovoltaics (PV) in traditional electric power systems. Energy Policy 2007, 35, 2852-2661. [CrossRef]

74. Denholm, P.; Margolis, R.M. Evaluating the limits of solar photovoltaics (PV) in electric power systems utilizing energy storage and other enabling technologies. Energy Policy 2007, 35, 4424-4433. [CrossRef]

75. Stodola, N.; Modi, V. Penetration of solar power without storage. Energy Policy 2009, 37, 4730-4736. [CrossRef]

76. Passey, R.J.; Watt, M.E.; Snow, M.; Outhred, H.R.; Spooner, T. Study of grid-connected photovoltaic systems: Benefits, opportunities and strategies. Prog. Photovolt. Res. Appl. 2009, 17, 419-431. [CrossRef]

77. Solomon, A.A.; Faiman, D.; Meron, G. An energy-based evaluation of the matching possibilities of very large photovoltaic plants to the electricity grid: Israel as a case study. Energy Policy 2010, 38, 5457-5468. [CrossRef]

78. Solomon, A.A.; Faiman, D.; Meron, G. The effects on grid matching and ramping requirements, of single and distributed PV systems employing various fixed and sun-tracking technologies. Energy Policy 2010, 38, 5469-5481. [CrossRef]

79. Solomon, A.A.; Faiman, D.; Meron, G. Appropriate storage for high-penetration grid-connected photovoltaic plants. Energy Policy 2012, 40, 335-344. [CrossRef]

80. Myers, K.S.; Klein, S.A.; Reindl, D.T. Assessment of high penetration of solar photovoltaics in Wisconsin. Energy Policy 2010, 38, 7338-7345. [CrossRef]

81. Widén, J.; Wäckelgard, E.; Lund, P.D. Options for improving load matching capability of distributed photovoltaics: Methodology and application to high-latitude data. Sol. Energy 2009, 83, 1953-1966. [CrossRef]

82. Zerhouni, F.Z.; Zegrar, M.; Benmessaoud, M.T.; Boudghene Stambouli, A.; Modoun, A. Optimum load matching by an array reconfiguration in photovoltaic generators. Energy 2010, 83, 1953-1966. [CrossRef]

83. Baetens, R.; De Coninck, R.; Helsen, L.; Saelens, D. The impact of domestic load profiles on the grid interaction of building integrated photovoltaic (BIPV) systems in extremely low-energy dwellings. In Proceedings of the Renewable Energy Research Conference, Trondheim, Norway, 7-8 June 2010; pp. 1-12.

84. Voss, K.; Candanedo, J.A.; Geier, S.; Gonzalves, H.; Hall, M.; Heiselberg, P.; Karlsson, B.; Musall, E.; Napolitano, A.; Sartori, I.; et al. Load matching and grid interaction of net zero energy buildings. In Proceedings of the EUROSUN 2010, International Conference on Solar Heating, Cooling and Buildings, Graz, Austria, 29 September-1 October 2010. 
85. Verbruggen, B.; De Coninck, R.; Baetens, R.; Saelens, D.; Helsen, L.; Driesen, J. Grid impact indicators for active building simulation. In Proceedings of the IEEE PES Conference on Innovative Smart Grid Technologies Conference, Anaheim, CA, USA, 17-19 January 2011.

86. Orioli, A.; Di Gangi, A. Load mismatch of grid-connected photovoltaic systems: Review of the effects and analysis in an urban context. Renew. Sustain. Energy Rev. 2013, 21, 13-28. [CrossRef]

87. Borenstein, S. The long-run efficiency of real-time electricity pricing. Energy J. 2005, 26, 93-116. [CrossRef]

88. Borenstein, S. Electricity Rate Structures and Economics of Solar PV: Could Mandatory Time-of-Use Rates Undermine California's Solar Photovoltaic Subsidies? Center for the Study of Energy Markets (CSEM) University of California Energy Institute, Berkeley Campus: Berkeley, CA, USA, 2007.

89. Lorenz, E.; Scheidsteger, T.; Hurka, J.; Heinemann, D.; Kurz, C. Regional PV power prediction for improved grid integration. Prog. Photovolt. Res. Appl. 2011, 19, 757-771. [CrossRef]

90. Short, W.; Packey, D.J.; Holt, T. A Manual for the Economic Evaluation of Energy Efficiency and Renewable Energy Technologies; National Renewable Energy Laboratory: Golden, CO, USA, 1995.

91. AEEG-Autorità per l'Energia Elettrica, il Gas e il Sistema Idrico. Available online: http://www.autorita. energia.it/it/dati/condec.htm (accessed on 9 November 2016).

92. Osterwald, C.R.; Anderberg, A.; Rummel, S.; Ottoson, L. Degradation analysis of weathered crystalline-silicon. NREL National Renewable Energy Laboratory. In Proceedings of the 29th IEEE PV Specialists Conference, New Orleans, LA, USA, 20-24 May 2002.

93. Jordan, D.C.; Smith, R.M.; Osterwald, C.R.; Gelak, E.; Kurtz, S.R. Outdoor PV degradation comparison. NREL National Renewable Energy Laboratory. In Proceedings of the 35th IEEE Photovoltaic Specialists Conference (PVSC), Honolulu, HI, USA, 20-25 June 2010.

94. Jordan, D.C.; Kurtz, S.R. Photovoltaic degradation rates-an analytical review. Prog. Photovolt. Res. Appl. 2013, 21, 12-29. [CrossRef]

95. SunPower Corporation. The Drivers of the Levelized Cost of Electricity for Utility-Scale Photovoltaics; SunPower Corporation: San Jose, CA, USA, 2008; pp. 1-27.

96. Price, S.; Margolis, R. 2008 Solar Technologies Market Report; Energy Efficiency \& Renewable Energy, US Department of Energy: Washington, DC, USA, 2010; pp. 1-131.

97. Heacox, E. Inverter Cost Analysis; Solar Industry: Abu Dhabi, UAE, 2010; pp. 28-31.

98. Branker, K.; Pathak, M.J.M.; Pearce, J.M. A review of solar photovoltaic levelized cost of electricity. Renew. Sustain. Energy Rev. 2011, 15, 4470-4482. [CrossRef]

99. AEEG-Autorità per l’Energia Elettrica, il Gas e il Sistema Idrico. Available online: http:/ / www.autorita. energia.it/it/comunicati/13/130125dmeg.htm (accessed on 9 November 2016).

100. AEEG-Autorità per l'Energia Elettrica, il Gas e il Sistema Idrico 2013. Available online: http://www. autorita.energia.it/it/comunicati/14/140130.htm (accessed on 9 November 2016).

101. Comuni Italiani. Available online: http://www.comuni-italiani.it/082/053/statistiche/redditi.html (accessed on 9 November 2016).

102. Comuni Italiani. Available online: http://www.comuni-italiani.it/058/statistiche/redditic.html (accessed on 9 November 2016).

103. Comuni Italiani. Available online: http://www.comuni-italiani.it/015/statistiche/redditic.html (accessed on 9 November 2016).

104. Istat-Italian National Institute of Statistics. Available online: http://www.istat.it/it/archivio/30440 (accessed on 9 November 2016).

105. Banca d'Italia. Available online: https://www.bancaditalia.it/compiti/operazioni-mef/rendistato-rendiob/ (accessed on 9 November 2016).

106. Directive 2009/28/EC of the European Parliament and of the Council of 23 April 2009 on the Promotion of the Use of Energy from Renewable Sources and Amending and Subsequently Repealing Directives 2001/77/EC and 2003/30/EC. Available online: http://eur-lex.europa.eu/legal-content/en/ALL/?uri= CELEX\%3A32009L0028 (accessed on 9 November 2016).

(C) 2016 by the authors; licensee MDPI, Basel, Switzerland. This article is an open access article distributed under the terms and conditions of the Creative Commons Attribution (CC-BY) license (http://creativecommons.org/licenses/by/4.0/). 